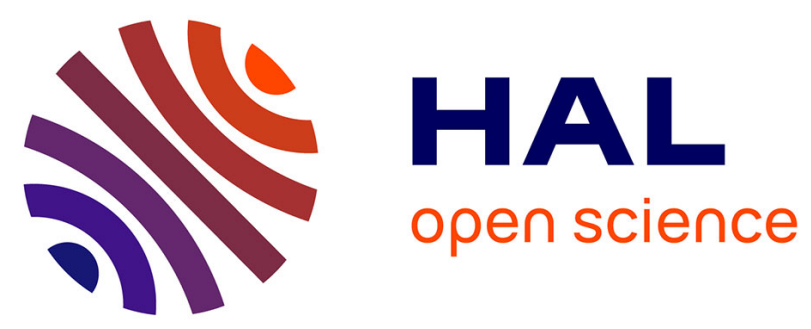

\title{
Eocene pre- and syn-obduction tectonics in New Caledonia (Southwest Pacific), a case for oblique subduction, transcurrent tectonics and oroclinal bending; structural and paleomagnetic evidence
}

Dominique Cluzel, Iseppi Marion, Yan Chen

\section{To cite this version:}

Dominique Cluzel, Iseppi Marion, Yan Chen. Eocene pre- and syn-obduction tectonics in New Caledonia (Southwest Pacific), a case for oblique subduction, transcurrent tectonics and oroclinal bending; structural and paleomagnetic evidence. Tectonophysics, 2021, 811, pp.228875. 10.1016/j.tecto.2021.228875 . insu-03207625

\section{HAL Id: insu-03207625}

\section{https://hal-insu.archives-ouvertes.fr/insu-03207625}

Submitted on 26 Apr 2021

HAL is a multi-disciplinary open access archive for the deposit and dissemination of scientific research documents, whether they are published or not. The documents may come from teaching and research institutions in France or abroad, or from public or private research centers.
L'archive ouverte pluridisciplinaire HAL, est destinée au dépôt et à la diffusion de documents scientifiques de niveau recherche, publiés ou non, émanant des établissements d'enseignement et de recherche français ou étrangers, des laboratoires publics ou privés. 


\section{Journal Pre-proof}

Eocene pre- and syn-obduction tectonics in New Caledonia (Southwest Pacific), a case for oblique subduction, transcurrent tectonics and oroclinal bending; structural and paleomagnetic evidence

Cluzel Dominique, Iseppi Marion, Chen Yan

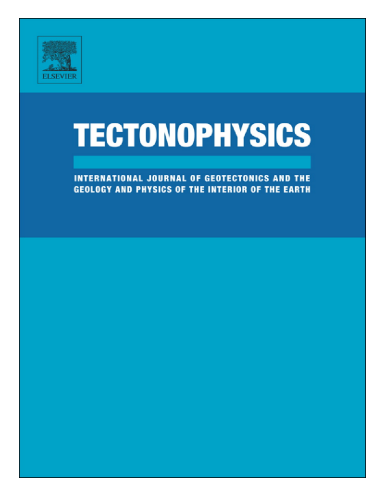

PII: $\quad$ S0040-1951(21)00159-1

DOI: $\quad$ https://doi.org/10.1016/j.tecto.2021.228875

Reference: $\quad$ TECTO 228875

To appear in: $\quad$ Tectonophysics

Received date: $\quad 29$ September 2020

Revised date: $\quad 8$ April 2021

Accepted date: $\quad 12$ April 2021

Please cite this article as: C. Dominique, I. Marion and C. Yan, Eocene pre- and synobduction tectonics in New Caledonia (Southwest Pacific), a case for oblique subduction, transcurrent tectonics and oroclinal bending; structural and paleomagnetic evidence, Tectonophysics (2021), https://doi.org/10.1016/j.tecto.2021.228875

This is a PDF file of an article that has undergone enhancements after acceptance, such as the addition of a cover page and metadata, and formatting for readability, but it is not yet the definitive version of record. This version will undergo additional copyediting, typesetting and review before it is published in its final form, but we are providing this version to give early visibility of the article. Please note that, during the production process, errors may be discovered which could affect the content, and all legal disclaimers that apply to the journal pertain.

(C) 2021 Elsevier B.V. All rights reserved. 
Eocene pre- and syn-obduction tectonics in New Caledonia (Southwest Pacific), a case for oblique subduction, transcurrent tectonics and oroclinal bending; structural and paleomagnetic evidence.

Cluzel Dominique ${ }^{1 *}$, Iseppi Marion ${ }^{1}$ and Chen Yan $^{2}$

${ }^{1}$ Université de la Nouvelle-Calédonie, Institut des Sciences Exactes et Appliquées (EA 7484), Avenue James Cook, 98850 Nouméa, New Caledonia

${ }^{2}$ Université d'Orléans, CNRS, BRGM, ISTO, UMR 7327, F-45071, -rléans, France

* corresponding author, dominique.cluzel@unc.nc

\section{Abstract}

The structural analysis of the metamorphic belt and ai - -ıthonous terranes, which represent the lower and upper plates of the Eocene subductio // $\mathrm{c}$ duction complex of New Caledonia respectively, unravels a multi-step evolution. At $\mathrm{s}$, hduction inception, the originally $\mathrm{N}-\mathrm{S}$ trending northern Norfolk/New Caledonia Ridge was no Ing northward as recorded by sheared lower Eocene dykes of the Peridotite Nappe. Fast exhu. nation of the fore-arc mantle in transtensional conditions was recorded by the injection of fore-a' $c 1$. 7 gnas through fast-cooling peridotites, followed by the occurrence of antigorite- and tremo'، hearing crack seals in small-scale transcurrent or oblique-slip faults. Meanwhile, slices of the $0^{-}$?anı crust of the lower plate were scrapped off and accumulated in the fore-arc region while scme t'?ments were dragged down into the subduction zone and contributed to the formati un $0^{-}$eclogite facies mélange. When the tip of the New Caledonia Ridge reached the trench, it pros assively jammed the subduction. Meanwhile, the oblique slip and coeval rotation of the arc due to the opening of the north Loyalty back-arc basin provoked the dextral transcurrent folding of already accreted ocean crust slices and metamorphic units on the course of exhumation. Bulk counterclockwise rotation of $56^{\circ} \pm 5^{\circ}$ was recorded in the foreland basin by paleomagnetic data of sediments from the 45-35 Ma time interval. The final obduction of fore-arc peridotites occurred with top-to-the-SW kinematics when the island had already reached its present orientation.

\section{Keywords}

Oblique subduction, fault analysis, supra-subduction dykes, transcurrent folding, paleomagnetism, oroclinal bending. 


\section{Introduction}

The current model of Eocene tectonics in New Caledonia, which postulates northeast-dipping pre-obduction subduction on the basis of structural, metamorphic and paleogeographic evidence is generally accepted (Aitchison et al, 1995; Carson et al., 1999; Clarke et al., 1997; Cluzel et al., 2001; Fitzherbert et al., 2003; Maurizot and Cluzel, 2014; Maurizot et al., 2020c; Spandler et al., 2003, 2004; Vitale Brovarone and Agard, 2003; Vitale Brovarone et al., 2017) and inferred by mantle structure (Schellart and Spakman, 2012; Van de Lagemaat et al., 2018) and plate tectonics reconstructions as well (Schellart et al., 2006; Whattam, 2008). How' 'er, due to the relatively small amplitude of the displacement, the kinematics of pre-obduction si odu tion is only roughly constrained by on land paleomagnetic data (Ali and Aitchison, ? Ui 2002; Dallanave et al., 2020; this study) and is therefore mainly based on structural evidence. 'ome reatures of the Eocene high pressure-low temperature (HP-LT) metamorphic belt, whi $=\mathrm{h} r \in$ 'ate to the lower plate of the obduction-subduction system, have not yet been consid red $_{1}$. this regard although they have long been known (Briggs et al., 1978; Lillie and Brothers, ., 70 , Maurizot et al., 1989; Maurizot and VendéLeclerc, 2009). In obducted peridotites, whic'، $r \in$, res nt the upper plate of the subduction-obduction system, pre-, syn- and post-obduction brittle $\mathrm{o}_{1}$-emi-brittle tectonic events are overprinted and may lead to confusion because they seem difficu'+ to unmix. Therefore, except for tectonic features of the serpentinite sole directly and obviously $r$ la ed to obduction (e.g., Gautier et al., 2016; Quesnel et al., 2016), a structural analysis based $n_{1}$. . accurately discriminated tectonic features is needed. Discrimination is possible on the ha. :s of the formation depth (temperature) and nature of associated minerals. For exampi - he occurrence of supergene minerals in crack seals (silica, garnierite, etc.) allows $\mathrm{i} \cdot \bullet_{1} \mathrm{r} r$ s snition of recent, shallow and dominantly gravity-driven tectonic events (Iseppi et al., 2018). ' shile ductile deformation in peridotites and associated magmatic rocks may be attributed to deep-seated mantle tectonics. In this article, the term "obduction" strictly means "overthrusting of ocean-type lithosphere elements upon continental crust" and only relates to the tectonic events involved in the final tectonic emplacement of New Caledonia Ophiolite, hereafter referred to as Peridotite Nappe (Avias, 1967).This study based on the analysis of geological maps (online geological map of New Caledonia, DIMENC, https://georep.nc/explorateur-cartographique), field structural analysis and paleomagnetic data, aims at identifying pre-obduction tectonic events to constrain the kinematics of Eocene subduction. For that end, analyses of existing geological maps and field surveys have been conducted in the Eocene HP-LT metamorphic belt, and in the allochthonous Poya Terrane and Peridotite Nappe. 


\section{Geologic setting}

New Caledonia is an elongate island $(400 \mathrm{~km} \times 45 \mathrm{~km})$ at the emerged northern tip of the Norfolk/New Caledonia Ridge, a narrow ribbon of continental nature, which forms the northern part of a continent-size largely submarine area of thinned continental crust referred to as Zealandia (Luyendyk, 1995; Mortimer et al., 2017). Zealandia was originally connected to Gondwana (Australia and Antarctica) and rifted during the Late Cretaceous (Uruski and Wood, 1991).

The Norfolk Ridge is bounded on both sides by deep-water basins, New Caledonia Basin to the southwest and Loyalty Basin to the northeast (Figure 1). The boundary i stween the Norfolk/New Caledonia Ridge and New Caledonia Basin is underlined by a strons 7sv nmetrical negative gravity anomaly (Collot et al., 1987; Van de Beuque, 1999) which conti. 'ues northward along the hookshaped D'Entrecasteaux Zone and disappears southward $a^{+}-\gamma<3^{\circ} \mathrm{S}$. In the New Caledonia Basin the gravity anomaly is due to the thick sedimentary infill onlab ${ }^{*}$-s a northeast-dipping Eocene seismic reflector (Collot et al., 2008). The New Caledonia Ba ,In ،17s an oceanic basement with a horizontal Moho to the south of $23^{\circ} \mathrm{S}$ and a thinned contine, al basement with a northeast-dipping Moho in the northern part (Klingerhoffer et al., 2007) wi. re ,t is in contact with the continental Lord Howe Rise through the Fairway Ridge. The Loyalty [\urcorner $\sin$ is asymmetrical as well and its oceanic basement dips to the northeast towards the Loyalty Ri $1 \mathrm{~g}$. 'Bıtoun and Récy, 1982). The boundary between New Caledonia Island and the Loyalty Bas, $\mathrm{n}$ :- rectilinear over more than $500 \mathrm{~km}$ and associated with a strong positive gravimetric anom ${ }^{-1} \mathrm{y} b$.leath the northeastern lagoon, which denotes the occurrence of dense mantle rocks near the su, 'xce. This linear feature represents the steeply dipping root of the ultramafic New Caledonia Jph, lite (Collot et al., 1987) referred to as Peridotite Nappe (Avias, 1967).

The geology of New ra edonia consists of: (1) pre-Late Cretaceous arc-derived basement terranes in relation to the Southeast Gondwana active margin (Meffre, 1995; Maurizot et al., 2020a) and Late Cretaceous to Eocene sedimentary cover (Maurizot et al., 2020b); (2) Eocene high pressurelow temperature metamorphic belt, which crops out in the northern part of the island (Maurizot et al., 2020c); and (3) two large allochthonous terranes: the mafic Poya Terrane emplaced in midEocene time and the ultramafic Peridotite Nappe obducted at the Eocene/Oligocene boundary, which together represent almost one half of island's surface (Fig. 1a) (Cluzel et al., 2012a; Maurizot et al., 2020c).

Fig. 1 Geological sketch map of New Caledonia 
The Peridotite Nappe (Avias, 1967) formed when the Loyalty Basin lithosphere was thrust upon the New Caledonia Ridge (Collot et al., 1987) when the latter reached the Loyalty subduction zone (Aitchison et al., 1995; Cluzel et al., 2001, 2017). It originally covered most of the island and extends further south on the submarine Norfolk Ridge (Patriat et al., 2018). Inception of the intra-oceanic subduction that finally led to obduction was recorded by the mafic metamorphic sole, dated at ca 56 $\mathrm{Ma}\left({ }^{40} \mathrm{Ar} /{ }^{39} \mathrm{Ar}\right.$ on hornblende and U-Pb on zircon overgrowths) (Cluzel et al., 2012b). The high temperature-low pressure thermal gradient $\left(\mathrm{ca} .60^{\circ} \mathrm{C} / \mathrm{km}\right)$ recorded by the granulite-facies metamorphic sole suggests that subduction started near a spreading ridge. Therefore, the involved lithosphere was buoyant and the subduction zone was shallow-dipping at start. Such a tectonic regime generated strong frictional forces at the plates interface (Esp · t et al., 2008; Gutscher et al., 2000) until older and colder parts of the lower plate reached the $s$ ' ba s stion zone and developed high pressure-low temperature metamorphism. Remarkably, th ert is no evidence for normal (MORtype) oceanic crust to exist on top of the ultramafic rocks. Tr.' strungly depleted harzburgites and dunites of the Peridotite Nappe are directly overlain by $k^{*}$ - -sci le mafic-ultramafic cumulate lenses; which consist of layered dunites, pyroxenites, wehrlites, webs arites and gabbronorites (enstatite gabbro) from the base upwards.

The Poya Terrane (or Poya Nappe) (Clu_ ग $f_{i}$ al., 1997; 2001) consists of a principal unit 10 to 20 $\mathrm{km}$ wide, which crops out over $160 \mathrm{~km}$ a' $\mathrm{n} n \mathrm{ng}$ the west coast of the island. Smaller km-sized lenses appear beneath the Peridotite Nappe c, $t, \sim$ Nassif du Sud, the northernmost massifs and along the east coast. It is composed of tectoni _ar.' sıced and duplicated uppermost oceanic crust rocks and passive margin turbidites intrude - by Iuwermost Eocene dolerite sills (Cluzel et al., 2017).

The Eocene HP-LT metamu. ${ }^{n}$. ic belt extends over ca $200 \mathrm{~km}$ along the northeastern coast of the island, from the northe $\left.\urcorner t_{1}\right\urcorner \cap f$ che island to Houaillou (Figure 1). It consists of two terranes: the Diahot-Panié Terrane, a dor inantly metasedimentary unit, and the Pouebo Terrane, a maficultramafic melange. The Diahot-Panié Terrane is principally composed of Late Cretaceous-Eocene meta-sediments and meta-volcanic rocks and volumetrically minor pre-Late Cretaceous metavolcaniclastic rocks. The Pouebo Terrane is an eclogite-facies melange formed of $\mathrm{cm}$ - to $\mathrm{km}$-size blocks enclosed in a meta-serpentinite matrix. Slices of lower grade mélange squeezed within the Diahot-Panié Terrane are referred to as Intermediate Melange (Cluzel, 2020). Components of the Pouébo Terrane and Intermediate Mélange come from the lower plate (Poya Terrane, Late Cretaceous-Paleocene metasediments) and to a lesser extent from the upper plate (serpentinite matrix, lowermost Eocene ( $55 \mathrm{Ma}$ ) fore-arc basin components: andesite pillow lavas and diorite dykes, and lower Eocene supra-subduction dykes) (Cluzel, 2020). 
The post-Early Cretaceous geological evolution may be summarized as follows:

- The rifting period (Late Cretaceous) is represented in the sedimentary cover of the Norfolk Ridge by coal-bearing shallow water marine sedimentation and moderate volcanic activity. Coeval coarse- to medium grain turbidites and black shales of the Diahot-Panié Terrane were accumulated in deep- water half-grabens, while distal passive margin turbidites characterize the Kone Facies (KF, Poya Terrane). Marginal rifting is generally attributed to the eastward rollback of the Pacific slab (e.g., Schellart et al., 2006), although no trace of a Late Cretaceous volcanic arc has been hitherto discovered (Cluzel and Meffre, 2018);

- The post-rift (oceanization) period was recorded by upperm $-i$ Cretaceous to mid-Eocene fining upward sequence, which recorded thermal subsidence whil $\mathrm{ma}_{\mathrm{a}}$ ginal basins opened on both sides of the Norfolk Ridge;

- A new northeast-dipping subduction started to the an ' of New Caledonia at the end of the Paleocene (> $56 \mathrm{Ma}$ ) (Cluzel et al., 2012b), it consumed mo _ f the South Loyalty Basin located to the east of Norfolk Ridge (Cluzel et al., 2001).

- From the mid-Eocene (ca $47 \mathrm{Ma}-45$ د I 'a); ' 'Tallanave et al., 2018, 2020) to the late Eocene (ca $34 \mathrm{Ma}$ ); (Cluzel et al, 1998) increasing instan "lity in the continental lower plate (the northern Norfolk Ridge) was recorded by input of fer, ' 'ginous argillite into the carbonate sedimentation, then occurrence of intraformational breccia $v$ er ain by 3-5 km thick upward coarsening turbidites. The latter accumulated in southeast-prc, agating foreland basin fed by parautochtonous imbricate thrusts (Montagne Blanches $\mathrm{Na}_{r}$ ne, (Maurizot, 2011) and from ca 40-38 Ma by the Poya Terrane



- At the end of the $\mathrm{L}_{\mathrm{r}}+\mathrm{e}$ Eocene $(<34 \mathrm{Ma})$, when the tip of the Norfolk Ridge reached the trench, the Loyalty Basin lithosphere was obducted without an on land sedimentary record.

The pre-obduction period thus covers the interval between $c a>56 \mathrm{Ma}$ (subduction inception) and ca $34 \mathrm{Ma}$ (final obduction in the south of the island). Tectonic events during this period have been recorded in the Eocene HP-LT metamorphic belt (lower plate) and in the allochthonous Poya Terrane (initially lower plate, then transferred to the upper plate) and Peridotite Nappe (upper plate) of the subduction-obduction system.

Tectonic events will be addressed hereafter in the chronological order (from subduction inception to obduction) and from top to bottom of the tectonic pile (Peridotite Nappe to metamorphic belt). 


\section{Tectonic records from the Peridotite Nappe}

The Peridotite Nappe is formed of a thin $(<2000 \mathrm{~m})$ sheet that rests almost horizontally upon underlying terranes $\left(<2^{\circ}\right.$ along the west coast), except along the east coast where the basal thrust marked by the serpentinite sole, 20 to $200 \mathrm{~m}$ thick, dips $30^{\circ}$ on average toward the northeast (Loyalty Basin); (Guillon, 1975). Kinematic indicators from the serpentinite sole generally indicate top-to-the-southwest motion (Gautier et al., 2016; Quesnel et al., 2013; Quesnel et al., 2016); locally however, some evidence for top-to-the-northwest and top-to-the-south motions may correspond to late/local movements of the allochthon.

\section{Internal structure}

The geometry of high temperature mantle fabric of the Peridc 'ite Jappe is quite different from that of the basal thrust and the dip of the foliation in peridotit $\epsilon$ - oft $2 n$ exceeds $20^{\circ}$ forming $\mathrm{km}$-scale open folds and may be upright in the vicinity of large high- $+\approx m_{\uparrow}$ rature shear zones. Until recently,

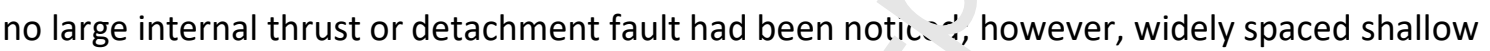
dipping discontinuities connected with the sole thru, $\tau$ r.ave been imaged by heliborne electromagnetic survey and interpreted as such (i: ?ppı, 2018). However, such a relatively simple structure sharply contrasts with the imbricá. $2 s^{\prime}$ ructure of the directly underlying Poya Terrane.

\section{Shear zones}

Three regional-scale high-temp $-r^{+}{ }^{+}$lie shear zones have been recognized: the Bogota Transform Fault oriented N20 E (Prinzhofer nd Nicolas, 1980; Titus et al., 2011), the Bélep Shear Zone oriented $\mathrm{N} 140^{\circ} \mathrm{E}$ (Nicolas, 1989; Sécher $19 \mathrm{1}$ ?; Titus et al., 2011), and the Humboldt Corridor trending $\mathrm{N} 165^{\circ} \mathrm{E}$ (Ferré et al., 2004; Vogt an 1 Pc Ivin, 1983) (Figure 1). These ductile shear zones are characterized by steeply dipping foliation $a_{1}$. 1 horizontal stretching lineation associated with dextral transcurrent motion. The current paleotransform interpretation of these shear zones, which connect laterally with the mantle fabric of Peridotite Nappe, suggests the occurrence of differently oriented spreading ridges, a common feature of back-arc basins (e.g. North Fiji Basin); (Auzende et al., 1995). However, there is no time constraint on the activity of these shear zones and their correlation with either the Late Cretaceous marginal basin stage or the Eocene fore-arc basin stage remains conjectural. Whatever the interpretation, these large-scale discontinuities and the associated fracture network most likely played a role during the pre-obduction period by reorienting local stress and channelizing supra-subduction fluids and magmas (see below). The occurrence of interstitial pargasite/edenite in the sheared peridotite followed by the development of upright lizardite seams parallel to the 
foliation recorded fluid-rock interaction at decreasing temperature within the shear zone system (Teyssier et al., 2016).

\section{Dykes}

The Peridotite Nappe is intruded by a variety of dykes, which vary in composition from ultramafic (pyroxenite) to mafic (gabbro, diorite, hornblendite, dolerite, boninite), and felsic (leucogabbro, leucodiorite, granite). They all display supra-subduction geochemical features and represent slab melts (adakite series), mantle wedge melts (boninite series) and juvenile mantle melts (island-arc tholeiites) (Cluzel et al., 2006). Their texture is generally coarse to medium-grained except basalt dykes, which display doleritic to microlithic texture. They are i- and independently of the structural level and nature of the ultramafic host rock (harzburgite du, ite or Iherzolite). Dykes never appear in underlying units, notably Poya Terrane, and thus prer atc obduction as confirmed by geochronological data (Cluzel et al., 2006). In general, the de sity of dykes, $10 \mathrm{~cm}$ to $10 \mathrm{~m}$ thick, is greater near the base of Peridotite Nappe except for doln ites, which are also present in the upper (cumulate) level of the nappe. The dykes are well preser ed in the main body of the ultramafic allochthon and in contrast, severely disrupted in the - 2 rr entinite sole.

Due to the large spacing, crosscutting I. 'lat' onships are rarely observed; however, dyke textures allow establishing a rough chronology. C thopyroxene grains of some pyroxenite dykes are nucleated in the harzburgite wall rock, some dyke, $a$ houdinaged in a ductile fashion (e.g. Poum Massif, Bogota Peninsula); (Titus et al., 2011 / a a a inus were intruded within a still hot peridotite. In contrast, although coarse-grained, most $\mathrm{fe}^{\prime}$ ic dy'kes were emplaced in a colder rock and developed anthophyllite-chlorite reaction rimı or no rims. Finally, dolerite/basalt dykes are fine to very fine grained, some display chill $: d \mathrm{n}$. rgins and have intruded cold host rocks.

Datable (zircon-bearins, dykes were emplaced between 55.5 Ma and 50 $\mathrm{Ma}$ (U-Pb on zircon) and IAT dolerite/basalt dykes at ca 50-47 Ma $\left({ }^{40} \mathrm{Ar} /{ }^{39} \mathrm{Ar}\right.$ ) (Cluzel et al., 2006, 2020 and unpubl. data) within an already existing fracture network of the host rock, as shown by straight boundaries and abrupt direction changes in a clearly dilatational setting (Figure 2).

\section{Fig. 2 Tiebaghi unsheared dykes}

Widespread coarse-grained felsic dykes suggest relatively slow cooling. In addition, pegmatitic (Figure 3) and sub-solvus textures and locally retrograde mineral associations suggest involvement of hydrous fluid. Depending on their age and orientation, some dykes underwent internal ductile deformation, which does not exist in the peridotite host (mineral boudinage, mineral preferred orientation, flow folding or microfolding, mylonitisation); (Figure 4 and Figure 5) and a compositional 
layering parallel to dyke walls is locally developed, thus suggesting high-temperature shearing and thus magma injection in active faults. Two-step intrusion is recorded by some dykes, which display a foliated part (earlier) while the rest of the dyke (later) displays granular texture (Figure 5). Thus shearing deformation only occurred during the early stage of dyke emplacement, a feature confirmed by radio-chronological data (see below). In contrast, younger IAT dolerite/basalt dykes display chilled margins, finer grain size, and lack secondary minerals. Dolerites have crystallized rapidly and were emplaced at lower temperature (i.e. later than most other dyke types) and in the absence of excess water.

Figures 3, 4 and 5 unsheared and sheared dykes

Dyke orientations do not fit a simple tension crack model sinc $\leq t w>$ or more sets of upright dykes commonly coexist (Figure 6). At island scale, there is no rear oreferential orientation; however, the dykes roughly cluster at $c a \mathrm{~N} 130 \mathrm{E}, \mathrm{N} 20^{\circ} \mathrm{E}$, and : 70 c; i.e., parallel or perpendicular to the main lineaments of the Peridotite Nappe. Magma wa inje ted through joints probably formed during the cooling of the ductile shear zones. For examp'?, ma.ic dykes of the Bogota Peninsula, in spite of some dispersion, cluster at ca. $\mathrm{N}^{\circ} 0^{\circ} \mathrm{E}\left(\mathrm{Titus}_{\mathrm{c}}{ }^{+}\right.$al 2011); (Figure 6), i.e., more or less parallel to the Bogota Shear Zone.

Fig. 6 structural analysis of Eocene a.,'kes

Sheared dykes mainly occur near $t_{1}$ f $b$ ise of Peridotite Nappe in the south of the island (Plum Pass, Ouen Island, Casy Islet) but thı alsu occur, although more scarcely, in northern massifs. Dextral motion is recorded by V.'NVi ESE trending sheared dykes while rare NNW-SSE trending dykes display sinistral motion (Figure $\iota^{-1}$. hus recording NW-SE directed shortening and NE-SW stretching directions.

Sheared diorite dykes, which occur to the southeast of Noumea (Plum Beach, Massif du Sud) have been dated at $c a 55 \mathrm{Ma}\left({ }^{40} \mathrm{Ar} /{ }^{39} \mathrm{Ar}\right.$ on hornblende); (Soret et al., 2016), which is a minimum age for magma injection and more probably represents the age of shearing deformation. Some amphiboles of the same group of outcrops yielded older Ar/Ar apparent ages (up to $92 \mathrm{Ma}$ ) (Soret et al., 2016); however, similar coarse-grained diorite dikes with the same orientation and composition, which crop out along the provincial road to Goro (Plum Pass) a few $100 \mathrm{~ms}$ from this outcrop, have been dated at ca $54 \mathrm{Ma}$ (U-Pb on zircon); (Cluzel et al., 2006). Therefore, anomalously older ages probably recorded some excess radiogenic argon. In fact, the inverse isochron plot (Soret et al., 2016; Figure S1) gives an apparent age of $86.5 \pm 7.5 \mathrm{Ma}$ and an intercept corresponding to the atmospheric argon. Ductile deformation of hornblende does not occur below $650-750^{\circ} \mathrm{C}$ in the presence of an 
aqueous fluid (Berger and Stünitz, 1996); therefore, older (Late Cretaceous) ages are likely due to synkinematic high-temperature fluid ingress, undetectable by the step-heating degassing method.

The coexistence of un-sheared nearly orthogonal dykes and specifically in the Massif du Sud, shallow dipping sills on the same sites, is consistent with dilatational conditions (i.e. multi-directional extension) after an early episode of NW-SE directed compression; however, the role of magma overpressure should not be neglected and the abundance of sills may be consistent with compressional context (i.e. vertical minimum stress) as well (Menand et al., 2010).

With the exception of Kopeto Massif where a lenticular NE-dipping dolerite dyke has been injected in a large serpentinised northeast-dipping normal fault (Fig $\omega^{2}=7$ ), dolerite dykes remain unaffected by internal deformation. Thus, dyke emplacement in th 2 u per plate started with NW-SE compression and finished with SW-NE extension in a context of at reasing temperature from 55.5 Ma to 50-47 Ma.

Fig. 7 lenticular dolerite dyke (Kopeto Massif)

\section{Antigorite and antigorite-tremolite crack sea's}

Small faults (shear joints) and tension $\mathrm{C}^{\prime} \mathrm{s}$ are widespread in the Peridotite Nappe (Figure 8). They occur by reactivation of lizardite-cl. vsotile vearing joints and are coated by synkinematic antigorite and antigorite-tremolite-bea in, rrack seals. Because antigorite and tremolite form at higher temperature than lizardite ar a hrysotile, the former record syntectonic high-temperature and Ca-rich fluid input. A connecti on with fluids emitted by the subduction zone, or having leached lower Eocene supra-subductinn $d y$ : $e s$ is suggested by their strontium and oxygen isotope signatures (Cluzel et al., 2019) and th's pı, ces them within or by the end of the 55-50 Ma interval.

Figure 8 antigorite and :remolite crack seals

Antigorite- and antigorite-tremolite-bearing crack seals do not fit Anderson's model (1951) of synchronous brittle failure and shear motion; instead, they correspond to the reactivation of (lizardite-coated) pre-existing fractures. Their spacing is variable and they may locally appear in swarms as an effect of strain localization due to the proximity of pre-existing regional-scale shear zones (e.g. Bogota Shear Zone, Humboldt Corridor) (Figure 1). The dominant directions of tension cracks/fault are roughly similar to that of supra-subduction dykes as they used the same pre-existing joint network.

The kinematic fault analysis based on fiber axis as a slip vector, shows a predominance of strikeslip and oblique-slip motion, which contrast with the dominant dip-slip motion of supergene faults 
(Iseppi et al., 2018). The main axes of the strain ellipsoid ( $X$ stretching, $Y$ intermediate, $Z$ shortening) computed with the with FaultKin program (Marrett and Allmendinger, 1990; Allmendinger et al., 2012) show three domains characterized by the orientation of the stretching axis $(X)$ of the strain ellipsoid: Massif du Sud (NNW-SSE), Kopeto-Boulinda and Poro (NNE-SSW), and Koniambo and Tiebaghi (ENW-ESE); (Figure 9). However, it appears that such differences are mainly due to the permutation of the principal strain axes. For example, in the Massif du Sud, the sites of Col Paillard and Vulcain Mine display similar orientation of the main stretching axis $(X)$ while the shortening $(\mathrm{Z})$ and intermediate (Y) axes are permutated. Similarly, Gemini Mine (Kouaoua) and Dunites 78 sites display permuted $Y$ and $Z$ axes (Figure 9). In the north, Koniambo and Tiebaghi sites correspond to the permutation of $X$ (main stretching axis) into $Y$ (intermediate), $X-d Y$ being horizontal and $X$ oriented WNW-ESE, i.e. at right angle to its orientation in the Mas' it a Sud. In the absence of folding or tilting strong enough and oriented accordingly to account fo pe mutation of main strain axes, such apparent complexity may simply result from permutatic 1 of principal stress axes $(\sigma 1 / \sigma 2$ or $\sigma 2 / \sigma 3)$ and thus of the principal axes of the resulting stre $\eta$ ell psoid $(X / Y$ and $Y / Z)$. Such an event may occur in brittle tectonic regime, even during a sino|c-stagt tectonic event (Angelier, 1989). The permutation of the main axes of the stress ellipsoi $x_{1}$ av easily occur at relatively shallow depth when the stress anisotropy is low.

Fig. 9 kinematic analysis of tremolite sntigorite crack seals

The kinematic analysis of antigorite In $^{\prime}$ a antigorite-tremolite crack seals infers that the Peridotite Nappe (i.e., the upper plate) was in . dominantly extensional or transtensional regime soon after the intrusion of felsic dykes, i.e. less tha, $6 \mathrm{My}$ after subduction inception.

\section{Tectonic records frr $m$ the Poya Terrane}

The allochthonous Poya Terrane (or Poya Nappe) (Cluzel et al., 1997, 2001, 2017) consists of an elongate unit $20 \times 180 \mathrm{~km}$ located on the west coast and smaller slices along the east coast and Massif du Sud, systematically located beneath the Peridotite Nappe (Figure 1). It is a composite lithotectonic unit composed of: 1) the Poya Terrane Basalts (PTB), MOR-type massive and pillow basalts associated with Campanian to lower Eocene abyssal argillite (Aitchison et al., 1995; Cluzel et al., 2001; Eissen et al., 1998), and 2) the Kone Facies (KF; Carroué, 1972), upper Cretaceous distal turbidites with minor fine-grained sandstone at the base and dark red or dark grey argillite on top, originally accumulated on the eastern passive margin of the Norfolk Ridge, intruded by $10 \mathrm{~m}$ to $100 \mathrm{~m}$ thick lower Eocene E-MORB sills (ca $55 \mathrm{Ma}$ ); (Cluzel et al., 2017). 
The basal thrust of the main unit forms a gentle synform except in the southern end near Bourail where it tightens above the back limb of the Montagnes Blanches ramp anticline. The top of the unit is formed by the almost horizontal $\left(<2^{\circ} \mathrm{dip}\right)$ basal thrust of the Peridotite Nappe. The complex internal structure of PTB, which consists of a stack of upright fault-bounded slices a few meters thick and a few 100 meters long (Figure 10), sharply contrast with the simple geometry of the limiting thrusts. It is worth noting that KF and PTB are not mixed and that the structure of the Kone Facies sub-unit is much simpler than that of PTB, as it lacks multiple tectonic slicing, denoting a distinct and much simpler tectonic evolution. Thus, imbrication of PTB predated amalgamation with KF. The PTB were scraped off the uppermost oceanic crust of the lower plate during the shallow-dipping subduction of the South Loyalty Basin and do not contain any othe. litt slogy than basalt and pelagic argillite. The tectonic slices were first accreted to the intra-oce, nic ${ }^{+}$Jre-arc region of the Loyalty Arc and then thrust over the leading edge of the New Caledon: Q quje (Cluzel et al., 2001). When it reached the margin, the PTB dragged large parts of the pas. $\because e$ margin turbidites of the Koné Facies and the whole set was thrust upon autochthonous/rar ${ }_{\wedge}$ 'tochthonous rocks of the New Caledonia Ridge where it fed syntectonic foreland basins ( $N_{1}$ : urizot and Cluzel, 2014). The main unit of the Poya Terrane (west coast) only displays low grade $m r$ iamorphism (zeolite-chlorite sub-greenschist facies) and thus was not buried deeply, while sc'-istosity is restricted to a narrow zone 200-300m thick beneath the Peridotite Nappe. In contr st nortions of the Poya Terrane (PTB and KF) were dragged down into the subduction zone and $\mathrm{r}_{\mathrm{t}}$ 'rvstallized into blueschists; as a consequence, discontinuous slivers of metamorphosed Poya T r rrarı rocks crop out along the east coast of New Caledonia (Hienghène region) (Cluzel et $\neg 1,2<17$ ). Radiochronologic dating of these relatively low grade metamorphic rocks was pr sver. difficult and no reliable data is available that could constrain diachronic accretion.

Fig. 10 typical exposure of Poya Terrane Basalts with upright sedimentary lenses

At island's scale, the orientation of sedimentary lenses in PTB, and of bedding and dolerite sills in KF display an average northwest-southeast strike; however, at all scales, open folds with vertical axes affect the average strike (Figure 11). With only a few exceptions these folds, especially the larger ones (several km), have a " $\mathrm{Z}$ " shape consistent with dextral transcurrent tectonics (transpression). However, to the northwest of the unit near Kaala-Gomen the vergence of the large fold is unclear due to the lack of outcrops in the littoral plain (Figure 11). The folds with vertical axes affect the PTB and KF but do not extend into the "autochthonous" basement of the unit, which 
displays a relatively simple structure (Figure 11). Thus, transcurrent folding occurred before the final tectonic emplacement of the terrane.

Fig. 11 Tectonic map of the Poya Terrane

The tectonic evolution of the Poya Terrane may therefore be summarized in four steps: 1 ) shallow-dipping subduction inception (Figure 12a); 2) Intra-oceanic tectonic accretion of the PTB in the fore-arc region (Figure 12b); 3) amalgamation of PTB and KF when the PTB reached the leading edge of the Norfolk Ridge and transcurrent dextral deformation (Figure 12c); and 4) thrusting of the already folded Poya Terrane (PTB + KF) "en bloc" onto the Norfolk Ridge. Meanwhile, elements of the PTB were dragged into the subduction zone with elements of the up $: r$ plate (supra-subduction mantle, fore-arc basin) where they recrystallized into blueschists a id $t$-logites as part of the Pouebo Melange (see below) (Cluzel, 2020).

Fig. 12 model for oblique subduction/accretion

\section{Tectonic records from the Eocene high $\mathrm{p}$. 'ssure - low temperature metamorphic belt}

The Eocene metamorphic belt extends ove - ca $225 \mathrm{~km}$ along the northeastern coast of New Caledonia (Fig. 1). Four main lithotectonic $u$. its may be distinguished on the basis of lithology and metamorphic grade: (1) Montagnes Blan hfs Nappe, (2) Diahot-Mt Panié Terrane, (3) Intermediate Melange units, and 4) Pouebo Mela. oe (ur Terrane). The metamorphic grade increases along a SWNE section from sub-greenschis, fac: गs (Potel et al., 2006) to eclogite facies (Clarke et al., 1997; Fitzhebert et al., 2003; Vitale BI w.rone and Agard, 2013) over a distance of about $20 \mathrm{~km}$. Such a steep increase implies '. 'at "is s srads" across strike are actually fault/thrust boundaries between sliced units of different yet $r$ ortheast-ward increasing metamorphic grade (Cluzel et al., 1995; Vitale Brovarone and Agard, 2013). Abrupt changes in style and intensity of ductile deformation are generally associated with these boundaries, which may be or not, associated with serpentinite or mélange slices. In contrast, the metamorphic grade gently decreases southeastward (along strike); a fact that suggests that subduction was dipping to the north or the north-northeast.

The timing of HP-LT metamorphism is well constrained in high grade units only. The peak metamorphic grade (eclogite facies) in the Pouebo Terrane has been dated at ca $44 \mathrm{Ma}$ (U-Pb zircon) (Spandler et al., 2005), it will be taken as the maximum age for exhumation inception. Eclogite facies rocks of the Diahot-Mt Panié Terrane yielded a younger peak metamorphic age at $c a 38 \mathrm{Ma}(\mathrm{U}-\mathrm{Pb}$ zircon) (Cluzel et al., 2010; Pirard \& Spandler, 2017). Both terranes yielded dispersed retrograde 
(blueschist/greenschist facies) ${ }^{40} \mathrm{Ar} /{ }^{39} \mathrm{Ar}$ ages on phengite and fuschite that cluster at ca $38 \mathrm{Ma}$ (40-28 Ma) (Baldwin et al., 2007; Ghent et al., 1994; Rawling, 1998). Finally, apatite fission tracks yielded an age of $34 \pm 4 \mathrm{Ma}$ for a closure temperature of $c a 150{ }^{\circ} \mathrm{C}$ (Baldwin et al., 2007).

The regional foliation associated with tight or isoclinal F1 folds is generally upright, except in the low grades zones. To the southwest across strike, near the peridotite klippes of the west coast, the dip quickly changes into $45^{\circ}$ to the northeast. Similarly, the foliation becomes shallow-dipping to the southeast of Touho fault and passes beneath the basal contact of Peridotite Nappe near Ponerihouen (Figures 1 and 13a). The structure of the high grade zone of the Mt Colnet-Mt Panié Massif escapes this general scheme and foliation in the northeastern part of the Diahot-Mt Panié Terrane forms a broad antiform, cored by the Pouebo Melange. The fold type changes $w^{\text {th }} \mathrm{h}$ lithology and with metamorphic grade from southwest to northeast, evolving from gt ntle to isoclinal. Northeastward, i.e. near the higher grade zone, F1 isoclinal folds are refolded ir. a $\mathrm{cr}$ ntinuum by tight F2 with roughly the same kinematics, thus resulting in complex outcrop pats $r r_{1}$. With only a few local variations due to subsequent F3 folding, the stretching lineation associate.' 'vith the regional foliation has an average west northwest-east southeast strike ( $N 70^{\circ}-0$ I average); (Figure 13b), not exactly perpendicular to the orientation of regional struc: ires. The regional foliation strikes northwestsoutheast on average; however, at all scales ' $m$. ter to several kilometers) the F1 and F1-2 fold axial surfaces, and the associated foliation an' 'serpentinite/melange slices display strike changes due to F3 open/close post-foliation folds with re isaı axes.

Fig. 13 tectonic map of the Eca ne metamorphic belt

At regional scale, three major -3 folds appear in Arama, Ouegoa and Touho-Poindimié areas (Figure 13a). The fold style evo, 'es with metamorphic grade from northwest to southeast (along strike) from close in Arama and Ouegoa areas to the Touho-Poindimié fold-fault (Figure13a). Similarly, the intensity of aeformation associated with these folds decreases southwestwards together with metamorphic grade. Asymmetrical folds with a " $Z$ " shape on map and on outcrop are consistent with dextral transpression (Figure 13b). Regarding the timing, F3 folds involve units of different metamorphic grade, which were previously juxtaposed along faults/thrusts and thus transcurrent folding is late- to post-exhumation (44-34 Ma).

\section{Paleomagnetic data}

Paleomagnetic studies attempted in New Caledonia (Tarling, 1967; Ali and Aitchison, 2000, 2002; Dallanave et al., 2018, 2020; Théveniaut et al., 2017) have proven difficult due to tectonic 
complexity, frequent remagnetization and prominent tropical weathering. With only rare exceptions, pre-Eocene terranes could not provide reliable data, probably due to the thermal effect of the Late Cretaceous rifting. In contrast, Eocene sedimentary rocks yielded some results in spite of feeble remanent magnetization.

The study of Ali and Aitchison $(2000,2002)$ focused on the early Permian Koh Ophiolite and Poya Terrane Basalts. Permian rocks did not allow a reliable paleomagnetic pole to be computed; however, in spite of tectonic complexity (see below), they could place the origin of Poya Terrane Basalts at about $300 \mathrm{~km}$ to the north of present-day New Caledonia.

Dallanave et al. $(2018,2020)$ carried out a magnetostratigraphic 'tudy in mid-Eocene hematitebearing calciturbidites from Noumea Peninsula and the moderatel / to, ted area to the east of Koumac (west coast, north of the island). The former site being an . listolith, the data could not be used for paleomagnetic pole computing; but with the latter $\quad x 4 \mathrm{IMa}$; site X, Fig. 1), a counterclockwise rotation of $\sim 60^{\circ}$ of New Caledonia with esp ct to Australia was evidenced and will be used in this article.

In order to test our tectonic interpretation $a_{1}$ y quantify the rotation at island's scale, a paleomagnetic study has been carried out $i_{1}$. th', southern half of the island in areas of the west coast that escaped Z-type transcurrent folding ?nd the effects of Eocene HP-LT metamorphism (Fig. 1). All samples were taken in shallow dipping ' $\mathrm{Je}$ :- on outcrops as fresh as possible with a portable gasoline driller (supplementary material, Tabe $=1$ ). Sampling for this study was performed on upper Eocene turbidites (38-34 Ma) from the Fl, sch cia Bourail near Noumea at Baie de Gadji (site A), along the main road from Bourail to Mcindo at Col des Arabes (site E), and Priabonian (ca. $35 \mathrm{Ma}$ ) Flysch de Bourail at La Roche Percée (Bo rail; site F), Lutetian (42 Ma ?) calcareous sandstones at the base of the Flysch de Bourail at Cu. Aymes (site G) and lower Eocene dolerite (ca. $50 \mathrm{Ma}$ ) from the Peridotite Nappe (Tontouta River, site H). Rocks from the sites $\mathrm{G}$ and H provided dispersed directions that could not be used in this study. Owing to the uncertainty of stratigraphic correlation of turbidites, an average age of $35 \mathrm{Ma}$ was collectively attributed to the three sites. Triassic to Paleocene formations were also sampled for paleomagnetic analysis but yielded complex remagnetization features, the analysis of which does not meet the aims of this article.

Details on the laboratory paleomagnetic analyses are provided as online supplementary information.

Magnetite with low concentration has been identified as the major magnetic remanence carrier by the hysteresis curve acquisition, thermo-magnetic experience and isothermal magnetic 
remanence measurement (Fig. S1). The degree of Anisotropy of Magnetic Susceptibility is less than 1.05 (Fig. S2), indicating that the sampled rocks have not experienced severe deformation after diagenesis. The remanence measurement of progressive demagnetization confirms weak magnetization ( $10^{-4} \mathrm{Am}^{2}$ for NRM; Fig. S3). Less than $50 \%$ of demagnetized specimens from only three sites present stable Characteristic Remanence Magnetization (ChRM), and two other sites did not provide any stable magnetic remanence (Table 1 ).

Table 1. Paleomagnetic results from southern New Caledonia. $n / N, D, l, \alpha, g$ and $s$ stand for statistic/total measured samples, declination, inclination cone radius of statistic confidence at 95\%, in-situ, bedding-corrected coordinates, respectively.

It is worth to note that: i) the directions of these sites are r..+Iviy compatible; ii) due to the small number of available specimens taken in statistical analı sis $\quad$ m each site, the statistical confidence level is relatively low; iii) due the small numbe ot ites, the age averages are calculated by specimen instead of site. Nevertheless, the age averaf, e $p_{1}$ vides reasonable results with acceptable statistical confidence level (Table 1). Bec w'se of the good compatibility among the three sites, one general average has been calculate $\therefore ; r\left({ }^{\circ}\right.$ age of $\sim 35 \mathrm{Ma}: D_{g}=341.1^{\circ}, I_{g}=-31.8^{\circ}, k=9.0$, $\alpha_{95 g}=14.0^{\circ} ; D_{s}=345.9^{\circ}, I_{s}=-36.7^{\circ}, k=11.0, \alpha_{3}=12.5^{\circ}$ and $n=14$ (Table 1 and Fig. 14).

Figure 14. Equal-area projection of tirec ions from Characteristic Remanence Magnetization (ChRM). a. directions in in-situ co rdinates; $b$. directions in bedding corrected coordinates.

The fold test (McElinn , 1 ?64; McFadden and McElinny, 1990) provides an inclusive answer due to weak variation of bedcing actitude; nevertheless, an improved precision parameter is obtained after bedding correction ( , able S1 and Fig. S4). With both normal and reversed magnetic polarities, the ChRM could be considered as primary magnetization (Figs. S3 and S4). Accordingly, a paleomagnetic pole has been calculated at: $\lambda=78.6^{\circ}, \phi=80.4^{\circ}, \mathrm{dp}=6.8^{\circ} ; \mathrm{dm}=11.6^{\circ}$ (Table 2 ).

Table 2. Comparison of paleomagnetic results from New Caledonia with Australian APWP

This new pole is not only distinct from that of the present Earth field, but also from that of Australia at $35 \mathrm{Ma}$ (Fig. 15); (Besse \& Courtillot, 2002, 2003). It also differs from the paleopole 
computed from slightly older sediments (ca. $45 \mathrm{Ma}$ ) near Koumac in the north of New Caledonia (Dallanave et al., 2020; see (Fig. 1, site X) and Fig.15). Table 2 reports their angular differences and their latitude and rotation components showing that latitudinal movements between New Caledonia and Australia are not really significant compared to rotations. Assuming the primary origin of ChRM of paleomagnetic data from New Caledonia, the new results show an counterclockwise rotation of $31.2^{\circ} \pm 9.6^{\circ}$ since $35 \mathrm{Ma}$ of New Caledonia with respect to Australia, confirming the tectonic evolution suggested by observations from other domains (Fig. 16).

However, there is a statistically significant difference between the southern part (this study) and the northern part of the island (Dallanave et al., 2020) with a bulk angular difference of $32.5^{\circ} \pm 8.3^{\circ}$ between their paleomagnetic poles (Table 2). Such a difference mav be, roduced by: 1) local rotations due to transcurrent folding (folds with vertical axes), 2) a. ${ }^{\mathrm{c} f e r}$.ntial rotation between the north and the south of the island; or, 3) progressive rotation th. oug । time. As described above (paragraph 5), the studied terranes have experienced supf $; n s, d$ deformations and especially folding with vertical axes that may account for local rotatio. - ,Fig. 13). The results from the northern site (site X; Dallanave et al., 2020) are derived from . $\mathrm{m}$ dşnetostratigraphic study, and thus correspond to a restricted area of a few hundred : vuare meters, lacking visible metamorphism and ductile deformation. The studied sequence . $m$ sderately dipping $\left(\sim 30^{\circ}\right.$ to the $\left.\mathrm{NE}\right)$ and monoclinal, preventing any fold test to be performeci However, the strike of F1-2 fold axes remains constant in this area over more than $20 \mathrm{~km}$ and thf re :- no evidence for F3 transcurrent folds with vertical axes (see paragraph 5). Results of this stı ay -ome from large monoclines, several km across strike, which show no evidence for transcurrer folus and thus no local rotation around vertical axes. The paleomagnetic data from the stua $: d$ areas may suggest that counterclockwise rotation of the northern part of the island was 'arger than that of the southern part; however, the island does not show bending at that scalt, which could account for $\sim 30^{\circ}$ differential rotation. An alternative interpretation may be proposed in term of chronology. The paleomagnetic data of Dallanave et al. (2020) are dated at $\sim 45$ Ma by micropaleontology and magnetostratigraphy, and show a counterclockwise rotation of $\sim 60^{\circ}$ of New Caledonia with respect to Australia, which is about $30^{\circ}$ more compared to our results from rocks dated at ca. $35 \mathrm{Ma}$ (Table 3). In other words, New Caledonia began its counterclockwise rotation with respect to Australia after ca. $45 \mathrm{Ma}\left(\sim 30^{\circ}\right)$ and continued after $35 \mathrm{Ma}\left(-30^{\circ}\right)$. Since no rotation relative to Australia was observed in the paleomagnetic record of Oligocene lateritic cuirasses (>25 Ma; Sevin et al., 2012) or late Oligocene granitoids (-25 Ma; Théveniaud et al., 2017), counterclockwise rotation ceased before $25 \mathrm{Ma}$. Unfortunately there is no on land sedimentary record for the period of 35-25 Ma and thus no precise constraint on the end of rotation. Owing to the small number of data, it clearly appears that these 
results are only qualitative and need to be comforted by a larger number of samples. However, evidence for about $60^{\circ}$ counterclockwise rotation, also reported by Théveniaut et al. (2017) supports the tectonic model presented below.

\section{Discussion: chronology and kinematics}

From subduction inception to obduction and from top to bottom of the tectonic pile, significant changes were recorded through time by pre-obduction tectonic events (Table 3 ). The oldest events associated with subduction inception did not leave any trace useful for kinematic analysis because they were greatly disturbed and possibly rotated by subsequent events (metamorphic sole) or disrupted by the melange process (earliest supra-subduction dykes and fore-arc basin rocks). Pyroxenite dykes and small-scale intrusions could not be dated and thu are difficult to relate to a given tectonic event. The earliest datable tectonic events appearec in +.10 Peridotite Nappe with lower Eocene sheared dykes (55.5-55 Ma), which unexpectedly recr ded NW-SE-directed compression and strike-slip motion. This event was short-1: $\gamma_{n}$ nd in the rest of the dyke complex emplacement period (55-50 Ma), wrench tectonics change. '. ,to multidirectional extension (dilatation). However, the role of magma pressure ir $\mathrm{tr}$. $s$ evolution should not be neglected because it tends to reduce the stress anisotropy and mav i sve resulted in nearly isotropic dilatation while the external stresses at regional scale remainec inr langed. From $55 \mathrm{Ma}$ to $50 \mathrm{Ma}$, however, the grain size reduction and appearance of non-r $\epsilon$. tional chilled margins signal relatively fast cooling of the fore-arc. In addition to a change in the nco $m$ ma source, island-arc dolerites, which emplaced from 50 Ma to $47 \mathrm{Ma}$, recorded WNW-ESE di i e ${ }^{+}$eu extension (Bogota Peninsula) or SW-NE directed extension (Kopeto Massif).

Antigorite- and tremolite-bea. ing crack seals recorded either transtension or nearly N-S extension depending upor the lace, as a consequence of principal stress permutation. The poorly fixed orientation of kinema ${ }^{~}{ }^{i} \mathrm{c}$ axes suggests low anisotropy of the stress ellipsoid and thus relatively shallow depth due to periaotite exhumation. Pre-existing discontinuities (e.g. regional-scale shear zones) may be suspected to have re-oriented the local stresses. In spite of some uncertainty on boundaries, the mineral sequence, i.e. lizardite $( \pm$ chrysotile $)=>$ antigorite + tremolite $=>$ antigorite $=>$ polygonal serpentine, provides some constraints on the evolution in temperature. The upper stability limit of lizardite ( \pm chrysotile) at low pressure $\left(<0.4 \mathrm{GPa}\right.$ ) is established to about $300-320^{\circ} \mathrm{C}$ (Evans, 2004), while antigorite stability starts at about $320^{\circ} \mathrm{C}$ and persists up to $500-550^{\circ} \mathrm{C}$ (Wenner and Taylor, 1971). At low to medium pressure (0.1-0.5 GPa) tremolite appears at $350-550^{\circ} \mathrm{C}$ and disappears at $400-650^{\circ} \mathrm{C}$ depending on the $\mathrm{CO}_{2}$ partial pressure (Jenkins, 1983; Chernosky et al., 1998; Evans, 2004; Evans et al., 2000, 2013). Therefore, the relative chronology above records: 1) a net increase in temperature after primary serpentinization due to the ingress of slab-derived fluids 
during the formation of tremolite-antigorite bearing veins, 2) a gentle temperature decrease at the end of tremolite crystallization, and 3 ) a final cooling down to supergene conditions (ca. $50^{\circ} \mathrm{C}-35^{\circ} \mathrm{C}$ ) (Cluzel et al., 2019). The predominance of strike-slip or oblique slip displacements denotes transtensional conditions in the upper plate consistent with oblique subduction (Chemenda et al., 2000; Gurnis et al., 2004; Gutscher et al., 1998, 2000).

In contrast with the weak and poorly time-constrained tectonics of the upper plate, the HP-LT belt and Poya Terrane display spectacular tectonic features, which directly relate to a specific tectonic event. Stacking and exhumation of HP-LT units probably occurred with a dominant ENEWSW (N70 ${ }^{\circ} \mathrm{E}$ ) direction recorded by the regional stretching lineation (Figure 13c, Table 3).

Notwithstanding the subsequent deformation by folds with ver ${ }^{\prime \prime}$ al axes, the initial orientation of the tectonic slices of the Poya Terrane was similar to that of the me. эmorphic belt (i.e. NW-SE in the present configuration of the island). Both terranes display t'ı _ - >me " $Z$ "-type folds denoting dextral transcurrent tectonics by the end of exhumation in $\mathrm{t}^{\prime}>\mathrm{Hr}-\mathrm{LT}$ belt and before final overthrusting of the Poya Terrane (Figure 13 \& Table 3).

Table 3 summary of Eocene tectonic events

Since transcurrent deformation is not expc-ted to occur during SW-directed (i.e. at right angle) overthrusting, it is assumed that dextral she -ring occurred before the island's scale counterclockwise rotation while the Australian Plate was $r$ ov ng northwards with respect to the coeval Loyalty Volcanic Arc. Counterclockwise rota ion of the northern Norfolk Ridge and coeval clockwise rotation of the $D^{\prime}$ Entrecasteaux zone we: ${ }^{\circ} \mathrm{r}_{\mathrm{c}}$-ponsible to the hook shape of the Loyalty-D'Entrecasteaux subduction zone. Therefore it $\mathrm{I}^{\mid \mathrm{i} l}$. ely that the northern Norfolk Ridge originally had an almost north-south direction, 1 , $\urcorner r_{c} r n$, sistent with the reconstruction of the ancient Gondwana margin than the present-day NW-St orientation (Figure 16a). The unexpected shortening direction (NW-SE) recorded by sheared dykes emplaced shortly after subduction inception was possibly due to northdirected subduction if the island is rotated back to its original N-S orientation. Oroclinal bending of the ridge could not be achieved without crust-mantle detachment (not to say subduction) along its western edge, and was made possible by the narrowness $(<100 \mathrm{~km})$ of the continental Norfolk Ridge; this point is supported by paleomagnetic data, which records post-mid-Eocene counterclockwise rotation of about $60^{\circ}$ (Dallanave et al., 2020; this study). Obduction of the Peridotite Nappe occurred during this rotation (Figure 16c).

Obduction was achieved after ca $34 \mathrm{Ma}$ in the south of the island (Cluzel et al., 1998) and continued farther south (Patriat et al., 2018) for an unknown period of time. Finally, to the southwest of New Caledonia, the incipient collision (or failed continental subduction) of the Lord Howe Rise 
with the northern Norfolk Ridge (Figure 16d) recorded by the local north-eastward dip of the Moho and uplift of Fairway Ridge, likely resulted in final blocking of the subduction at the latitude of New Caledonia. As a consequence, increasingly fast eastward rollback of the VTK subduction in Oligocene time (> $30 \mathrm{Ma}$; van de Langemaat et al., 2018) accompanied the continuous opening of the North Loyalty/South Fiji back-arc basin.

8. Fig. 16 model for the evolution of the SW Pacific between $56 \mathrm{Ma}$ and $30 \mathrm{Ma}$ 


\section{Conclusions}

From subduction inception to obduction, tectonics occurred at decreasing temperature and pressure in the Peridotite Nappe (upper plate) and in the HP-LT metamorphic belt (lower plate pro parte). Such decrease associated with exhumation of the HP-LT belt and uplift of Peridotite Nappe is recorded by the changing style of tectonic structures and associated mineralization (Table 3).

Shortly after subduction inception, the shortening direction recorded by deformed lower Eocene dykes in the upper plate was parallel to the present NW-SE strike of the island. Owing to the counterclockwise rotation deciphered by paleomagnetic data during the 45-25 Ma time interval, the shortening direction was roughly oriented N-S at start and the Austr. 'an Plate was moving northwards with respect to the Pacific Plate.

Distal turbidites of the late Cretaceous passive margin (Ko, @ F $\check{c}$ zies) were intruded by prominent lower Eocene (ca. $55 \mathrm{Ma}$ ) E-MORB dolerite sills. This featur = is $\iota$ nsistent with extension (bulging and/or transtension ?) in the lower plate (Australian Plate . ‘ he system (Cluzel et al., 2017) shortly after subduction inception.

The progressive counterclockwise orocl' , al jen''ing of the New Caledonia/northern Norfolk Ridge due to the blocking of this narrow slice $c$. r ontinental crust in the subduction zone could not be achieved without SE-propagating jump-bac. of the subduction. Thus, the northern Norfolk Ridge was sandwiched between two lithospheres: t'ie _oyalty fore-arc to the NE and the Australian Plate to the SW, which moved obliquely to each, ther. Counterclockwise rotation of the New Caledonia Ridge was achieved through rotation c rou. $d$ a vertical axis located on the ridge at about $23^{\circ} \mathrm{S}$ latitude. This point actually correspond to the cr uthern end of the negative gravity anomaly, which follows the ridge for about $800 \mathrm{~km} \cdot \mathrm{ni}_{\mathrm{i}}$ ar out $18^{\circ} \mathrm{S}$ and less continuously along the hook-shaped $D^{\prime}$ Entrecasteaux Ridge wher 2 it disappears beneath the Vanuatu trench at about $15^{\circ} \mathrm{S}$.

Slices of Poya Terrane Basalts, which were scrapped off from the crust of the lower plate (South Loyalty Basin) and accreted to the Loyalty fore-arc were amalgamated with Late Cretaceous turbidites of the ancient passive margin (Kone Facies) and affected by dextral Z-type transcurrent folds before being thrust "en bloc" in mid-Eocene times, thus recording a change in kinematics due to slab roll back, progressive opening of the North Loyalty back-arc basin and coeval rotation of the Loyalty Arc.

By the end of exhumation of the HP-LT terranes, which started after $44 \mathrm{Ma}$ (Spandler et al., 2005) and was almost completed at ca $34 \mathrm{Ma}$ (Baldwin et al., 2007), the development of dextral 
transcurrent folding in the metamorphic belt signals that transpression and thus oblique subduction was continuing.

Younger strike-slip faults that crosscut the Peridotite Nappe front and post-obduction granitoids suggest ongoing post-obduction transcurrent tectonics (transtension ?), which is however beyond the scope of this article.

\section{Acknowledgements}

Parts of this study come from M.I. PhD thesis co-funded by BRGM, L' $\complement$, the Geological Survey of New Caledonia and CNRT “Nickel et son Environnement” (project r,ph, ᄀStruct). M.I. warmly thanks B. Lebayon, and D. Lahondère (BRGM), S. Lesimple, P. Maurizot ar a L kobineau (SGNC) for welcome during her stay in New Caledonia, communicating some stru- - ura data and assistance in the field. The nickel mining companies of New Caledonia are also r.llec ively acknowledged for permitting access and logistical support during field work in mine sit es. Lr.3EX VOLTAIRE (ANR-10-LABX-100-01) and EQUIPEX PLANET (ANR-11-EQPX-0036) are apnr.'.lat ¿d. Comments by anonymous reviewer are also greatly appreciated. 


\section{Credit Author Statement}

D. Cluzel : conceptualization, field investigation, paleomag sampling, map analysis, writing and designing ; M. Iseppi : field investigation, kinematic fault analysis ; Y. Chen : paleomagnetic analysis, writing supplementary data section

\section{Declaration of interests}

The authors declare that they have no known competing financial interests or personal relationships that could have appeared to influence the work reported in this paper.

\section{References}

Aitchison, J., Clarke, G., Meffre, S. and Cluzel, D. (1995). Eocene arc-continent collision in New Caledonia and implications for regional southwest Pacific tectonic evolution. Geology, 23, 161-164. https://doi.org/10.1130/0091-7613(1995)023<0161:EACCIN>2.3.CO;2

Ali J.R., and Aitchison J.C. (2000). Significance of palaeomar, $\ldots+$ IC uata from the oceanic Poya Terrane, New Caledonia, for SW Pacific tectonic models. Eart.। aıı' rlanetary Science Letters 177, 153-161. https://doi.org/10.1016/S0012-821X(00)00042- .

Ali J.R., and Aitchison J.C. (2002). Paleomagnetir - stonic study of the New Caledonia Koh Ophiolite and the mid-Eocene obduction of the P va ı ırane. New Zealand Journal of Geology and Geophysics 45, 313-322. https://doi.org/10 · 08',/00288306.2002.9514976

Allmendinger, R. W., Cardozo, N., ana -isher, D. M. (2011). Structural geology algorithms: Vectors and tensors. Cambridge Univer jił y , ess. https://doi.org/10.1017/CBO9780511920202

Anderson, E.M. (1951). The Г.yna, rics of Faulting, 206 pp., Oliver and Boyd, London

Angelier J. (1989). From $0_{1}:{ }^{\dagger}{ }^{\dagger}$ ation to magnitudes in paleostress determinations using fault slip data. Journal of Structı "al ieol gy 11, 1-2, 37-50. https://doi.org/10.1016/0191-8141(89)90034-5

Auzende J.-M., Pelleıır B., and Eissen J.-P. (1995). The North Fiji Basin : geology, structure and geodynamic evolution. In : Taylor B. (Ed.) Back-arc Basin : tectonics and magmatism. Plenum Press, New York, 139-175.

Avias J. (1967). Overthrust structure of the main ultrabasic New Caledonian massives. Tectonophysics, 4, 4-6, 531-541. https://doi.org/10.1016/0040-1951(67)90017-0

Baldwin, S.L., Rawling, T. \& Fitzgerald, P.G. (2007). Thermochronology of the New Caledonian high-pressure terrane: Implications for middle Tertiary plate boundary processes in the southwest Pacific. Geological Society of America Special Papers, 419, 117-134. 
Berger A. and Stünitz H. (1996). Deformation mechanisms and reaction of hornblende: examples from the Bergell tonalite (Central Alps). Tectonophysics 257, 2-4, 149-174 https://doi.org/10.1016/0040-1951(95)00125-5

Besse, J., and Courtillot V. (2002). Apparent and true polar wander and the geometry of the geomagnetic field over the last 200 Myr, J. Geophys. Res., 107(B11), 2300, https://doi.org/10.1029/2000JB000050

Besse J. and Courtillot V. (2003). Correction to "Apparent and true polar wander and the geometry of the geomagnetic field over the last 200 Myr", J. Geophys. Res., 108(B10), 2469, https://doi.org/10.1029/2003JB002684

Bitoun, G., and Récy, J. (1982). Origine et évolution du bassin i'os I Jyauté et de ses bordures après la mise en place de la série ophiolitique de Nouvelle-Calé 'oni :. Contribution à l'étude géodynamique du sud-ouest Pacifique. Travaux et documf *c ? ?STOM, Paris, 505-539.

Briggs, R.M., Lillie, A.R. and Brothers, R.N. (1978). St. uctu. a and high-pressure metamorphism in the Diahot region northern New Caledonia. Bulletin \ 1 B $G$ GM, Section IV, 3, 171-189.

Carroué J. P. (1972). Carte et notice ex $x^{\prime}{ }^{i c}$.ive de la carte géologique de la Nouvelle-Calédonie à I'échelle du 1/50000: feuille Pouembout. Bureau de Recherches Géologiques et Minières, Orléans France.

Carson, C.J., Powell R., Clarke C I.. (1999). Calculated mineral equilibra for eclogites in CaONa2O-FeO-MgO-Al2O3-SiO2-H2 ר: a plication to the Pouebo Terrane, Pam Peninsula, New Caledonia. Journal of Metamnrphi, Geology, 17, 9-24. https://doi.org/10.1046/j.15251314.1999.00177.x

Chemenda A., Lallemand S., Bokun A. (2000). Strain partitioning and interplate friction in oblique subduction zones: Constraints provided by experimental modeling. Journal of Geophysical Research 105, B3, 5567-5581. https://doi.org/10.1029/1999JB900332

Chernosky J.V., Berman R.G., and Jenkins D.M. (1998). The stability of tremolite: new experimental data and a thermodynamic assessment. American Mineralogist 83, 726-739. https://doi.org/10.2138/am-1998-7-805

Clarke G., Aitchison J.C., and Cluzel D. (1997). Eclogites and blueschists of the Pam Peninsula, NE New Caledonia: a reappraisal. Journal of Petrology 38, 7, 843-876.

https://doi.org/10.1093/petroj/38.7.843 
Cluzel D. (2020). Subduction erosion; contributions of footwall and hanging wall to subduction melange; field, geochemical and radiochronological evidence from the Eocene HP-LT belt of New Caledonia. Australian Journal of Earth Sciences 68, 1, 99-119. https://doi.org/10.1080/08120099.2020.1761876

Cluzel D., Aitchison J., Clarke G., Meffre S. et Picard C. (1995). Dénudation tectonique du complexe à noyau métamorphique de haute pression tertiaire (Nord de la Nouvelle-Calédonie, Pacifique, France), Données cinématiques. Comptes Rendus Académie des Sciences Paris 321, 57-64

Cluzel D., Picard C., Aitchison J., Laporte C., Meffre S. and Parat F. (1997). La Nappe de Poya (exFormation des basaltes) de Nouvelle-Calédonie (Pacifique SW), un $p_{1}$ eau océanique CampanienPaléocène supérieur obducté à l'Eocène supérieur. Comptes Rend' is A، adémie des Sciences Paris. 324, 443-451.

Cluzel D., Chiron D. et Courme M.D. (1998). Discordar = a a !'Eocène supérieur et événements pré-obduction en Nouvelle-Calédonie (Pacifique sud-ouest, _umptes Rendus Académie des Sciences Paris 327, 485-91.

Cluzel D., Aitchison J.C., and Picard C. (2', $\mathrm{O}_{\perp}$. Tt tonic accretion and underplating of mafic terranes in the Late Eocene intraoceanic fore-a. - of New Caledonia (Southwest Pacific). Geodynamic implications. Tectonophysics 340, 1-2, 23-6i https://doi.org/10.1016/S0040-1951(01)00148-2

Cluzel D., Meffre S., Maurizot P, C эvvrord A.J. (2006). Earliest Eocene (53 Ma) convergence in the Southwest Pacific; evidence f $>\mathrm{m}$ w.e-obduction dikes in the ophiolite of New Caledonia. Terra Nova, 18, 395-402. https://doi.org,'1.0.1111/j.1365-3121.2006.00704.x

Cluzel, D., Adams, - I., Me ire, S., Campbell, H.J. and Maurizot, P. (2010). Discovery of Early Cretaceous Rocks in New $\mathrm{Cr}$ edonia: New Geochemical and U-Pb Zircon Age Constraints on the Transition from Subduction to Marginal Breakup in the Southwest Pacific. Journal of Geology, 118, 381-397, https://doi.org/10.1086/652779

Cluzel D., Maurizot P., Collot J. and Sevin B. (2012a). An outline of the Geology of New Caledonia; from Permian-Mesozoic Southeast-Gondwanaland active margin to Tertiary obduction and supergene evolution. Episodes 35, 1, 72-86. http://doi.org/10.18814/epiiugs/2012/v35i1/007

Cluzel D., Jourdan F., Meffre S., Maurizot P., and Lesimple S. (2012b). The metamorphic sole of New Caledonia ophiolite; ${ }^{40} \mathrm{Ar} /{ }^{39} \mathrm{Ar}, \mathrm{U}-\mathrm{Pb}$, and geochemical evidence for subduction inception at a spreading ridge. Tectonics. 31, 3, https://doi.org/10.1029/2011TC003085,2012 
Cluzel D., Whitten M., Meffre S., Aitchison J.C., and Maurizot P. (2017). A reappraisal of the Poya Terrane (New Caledonia). Accreted Late Cretaceous marginal basin upper crust, passive margin sediments and Eocene E-MORB sill complex. Tectonics 37, 1, 48-70. https://doi.org/10.1002/2017TC004579

Cluzel D. and Meffre S. (2018). In search of Gondwana heritage in the Outer Melanesian Arc: no pre-Upper Eocene detrital zircons in Viti Levu river sands (Fiji Islands). Australian Journal of Earth Sciences 66(2), 265-277. https://doi.org/1080/08120099.2019.1531924

Cluzel D., Boulvais Ph., Iseppi M., Lahondère D., Lesimple S., Maurizot P. Paquette J.L., Tarantola A., and Ulrich M., (2019). Slab-derived origin of tremolite-antigorite " ins in a supra-subduction ophiolite; the Peridotite Nappe (New Caledonia) as a case study. Ir ierı. 7tional Journal of Earth Sciences 109(1), 171-196 https://doi.org/10.1007/s00531-019-r,1,?6-6

Collot J.Y., Malahoff A., Recy J., Latham G., and Misser;.ว r. (1987). Overthrust emplacement of New Caledonia ophiolite : geophysical evidence, Tectonics, - s, p. 215-232. https://doi.org/10.1029/TC006i003p00215

Collot, J., Geli L., Lafoy Y., Vially R., Cluzf، D. Klı.gelhoefer F., and Nouzé H. (2008). Tectonic history of northern New Caledonia Basin from i'sep offshore seismic reflection: Relation to late Eocene obduction in New Caledonia, south v : ast Pacific, Tectonics, 27, TC6006, https://doi.org/10.1029/2008TC002263

Dallanave, E., Agnini C., Pasc' er K..M., Maurizot P., Bachtadse V., Hollis C.J., Dickens G.R., Collot J., and Monesi E. (2018). Magnetc biostratigraphic constraints of the Eocene micrite-calciturbidite transition in New Caledoni «: te tonic implications, New Zealand Journal of Geology and Geophysics, 61(2), 145-163, https://do. . rg/10.1080/00288306.2018.1443946

Dallanave, E., Maurizot, P., Agnini, C., Sutherland, R., Hollis, C. J., Collot, J., et al. (2020). Eocene (46-44 Ma) onset of Australia-Pacific plate motion in the southwest Pacific inferred from stratigraphy in New Caledonia and New Zealand. Geochemistry, Geophysics, Geosystems, 21, e2019GC008699. https://doi.org/10.1029/2019GC008699

DIMENC, Gouvernement de la Nouvelle-Calédonie, online geological map of New Caledonia https://dtsi-sgt.maps.arcgis.com/apps/webappviewer/index.html accessed 03/2020-05/2020.

Espurt, N., Funiciello, F., Martinod, J., Guillaume, B., Regard, V., Faccenna, C., and Brusset, S., (2008). Flat subduction dynamics and deformation of the South American plate: Insights from analog modeling: Tectonics, v. 27, TC3011, https://doi.org/10.1029/2007TC002175 
Eissen, J.P., Crawford, A.J., Cotten J., Meffre S., Bellon H., and Delaune M. (1998). Geochemistry and tectonic significance of basalts in the Poya Terrane, New Caledonia. Tectonophysics, 284, 203219. https://doi.org/10.1016/S0040-1951(97)00183-2

Evans B.W. (2004). The serpentinite multisystem revisited: chrysotile is metastable, International Geology Review 46:6, 479-506. http://dx.doi.org/10.2747/0020-6814.46.6.479

Evans B.W., Ghiorso M.S., and Kuehner S.M. (2000). Thermodynamic properties of tremolite: A correction and some comments. Amer. Miner. 85, 3-4, 466-472. https://doi.org/10.2138/am-20000407

Evans B. W., Hattori K., and Baronnet A. (2013). Serpentinite: Wha,, Why, Where? Elements 9, 99-106. https://doi.org/10.2113/gselements.9.2.99

Ferré, E.C., Belley, F., Tikoff, B., Martín-Hernández, F., N ’ skwe, G. and Ward, C. (2004). Anatomy of an oceanic mantle shear zone deduced from high-field nag etic anisotropy: the Humboldt corridor, New Caledonia. Eos Trans. AGU, 85(47), Fall M _etins Supplement, Abstract GP23B-04.

Fitzherbert, J.A., Clarke, G.L. and Powell, R. ( 2 703). Lawsonite-Omphacite-bearing metabasites of the Pam Peninsula, NE New Caledonia: Evid' ncr for disrupted blueschist- to eclogite-facies conditions. Journal of Petrology, 44, 18C--1831. https://doi.org/10.1093/petrology/egg060

Gautier, P., Quesnel, B., Boulvais, 1. ın 1 Cathelineau, M. (2016). The emplacement of the Peridotite Nappe of New Caledonia nd irs bearing on the tectonics of obduction. Tectonics, https://doi.org/10.1002/2016TC104?18

Ghent, E., Roddick, J. nd : lack, P. M. (1994). ${ }^{40} \mathrm{Ar} /{ }^{39} \mathrm{Ar}$ dating of white micas from the epidote to the omphacite zones, nor i arn New Caledonia: tectonic implications. Canadian Journal of Earth Sciences, 31, 995-1001.

Guillon, J.H. (1975). Les massifs péridotitiques de Nouvelle-Calédonie; Type d'appareil ultrabasique stratiforme de chaîne récente. Mémoire ORSTOM, Paris, 76, 1-72.

Gurnis, M., Hall C., and Lavier L. (2004), Evolving force balance during incipient subduction, Geochem. Geophys. Geosyst., 5, Q07001, https://doi.org/10.1029/2003GC000681

Gutscher M.A., Kukowski N., Malavieille J. and Lallemand S. (1998). Material transfer in accretionary wedges from analysis of a systematic series of analog experiments. Journal of Structural Geology 20, 4, 407-416. https://doi.org/10.1016/S0191-8141(97)00096-5 
Gutscher M.A, Spakman W., Bijwaard H., and E. Engdah R. (2000). Geodynamics of flat subduction: Seismicity and tomographic constraints from the Andean margin. Tectonics 19, 5, 814833. https://doi.org/10.1029/1999TC001152

Iseppi M. (2018). Fracturation polyphasée et contrôles des gisements de nickel supergène de Nouvelle-Calédonie. Nouvelles méthodes d'exploration et modèles de gisements. PhD thesis University of New Caledonia. 301 p.

Iseppi M., Sevin B., Cluzel D., Le Bayon B. and Maurizot P. (2018). Supergene nickel ore deposits controlled by gravity-driven faulting and slope failure (Peridotite Nappe, New Caledonia). Economic Geology 113, 2. https://doi.org/10.5382/econgeo.2018.4561

Jenkins D.M. (1983). Stability and composition relations of cal 'ic a' nphiboles in ultramafic rocks Contributions to Mineralogy and Petrology 83, 3-4, 375-384, ht ns:/ 'doi.org/10.1007/BF00371206

Klingelhoefer, F., Lafoy Y., Collot J., Cosquer E., Géli ! . No Izé H., and Vially R. (2007), Crustal structure of the basin and ridge system west of New Calc donla (southwest Pacific) from wide-angle and reflection seismic data, J. Geophys. Res., 112, B. ${ }^{1} 10_{-}$, https://doi.org/10.1029/2007JB005093

Lahondère D. (2012). Atlas des occurre, rer et des types de fibre d'amiante sur mine. Rapport BRGM/RP-61426-FR, final report.

Lillie A. R. and Brothers R. N. (197C). The geology of NewCaledonia, New Zealand Journal of Geology and Geophysics, 13:1, 145- 83, rittps://doi.org/10.1080/00288306.1970.10428210

Luyendyk, B. P. (1995). Hvpot, ?sis for Cretaceous rifting of east Gondwana caused by subducted slab capture. Geology, 23(/), 3,3-376, https://doi.org/10.1130/と $717613(1995) 023<0373: H F C R O E>2.3 . C O ; 2$

Marrett, R.A. and Allmendinger, R.W. (1990). Kinematic analysis of fault-slip data. Journal of Structural Geology, 12, 973-986. http://dx.doi.org/10.1016/0191-8141(90)90093-E

Maurizot P. (2011). First sedimentary records of the pre-obduction convergence in New Caledonia: Formation of an accretionary complex during early Eocene in the North of the Grande Terre and emplacement of the Montagnes Blanches nappe. Bulletin de la Société Géologique de France, 182(6): 479-491. https://doi.org/10.2113/gssgfbull.182.6.479

Maurizot P., Eberlé J.M., Habault C., and Tessarolo C. (1989). Carte géologique Territoires d'Outre-Mer, Nouvelle-Calédonie (1/50000), feuille Pam-Ouégoa, 2e édition, B.R.G.M. France. Notice explicative par Maurizot P., Eberlé J.M., Habault C., Tessarolo C., 81p. 
Maurizot P., and Vendé-Leclerc M. (2009). New Caledonia geological map, scale 1/500 000, DIMENC - SGNC, BRGM. Explanatory note by Maurizot P. and Collot J.

Maurizot, P., and Cluzel, D. (2014). Pre-obduction records of Eocene foreland basins in central New Caledonia (Southwest Pacific); an appraisal from surface geology and Cadart 1 borehole data. New Zealand Journal of Geology and Geophysics, 57, 3, 307-311. https://doi.org/10.1080/00288306.2014.885065

Maurizot, P., Cluzel, D., Meffre, S., Campbell, H.J., Collot, J., and Sevin, B. (2020a). Pre-Late Cretaceous basement terranes of the Gondwana active margin of New Caledonia. In: Maurizot P., and Mortimer, N. (ed.) New Caledonia: Geology, Geodynamic Evolui ', in and Mineral Resources. Geological Society, London, Memoirs, 51. https://doi.org/10.1144/Ms:-2016-11

Maurizot, P., Bordenave, A., Cluzel, D., Collot, J., and Etien. 'e, S (2020b). Late Cretaceous to

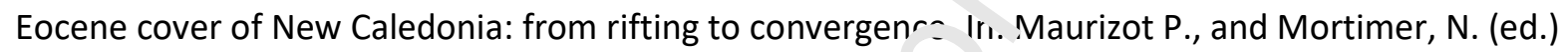
New Caledonia: Geology, Geodynamic Evolution and Mineı -' 'iesources. Geological Society, London, Memoirs, 51, https://doi.org/10.1144/M51-2017-18

Maurizot, P., Cluzel, D., Patriat, M., Collr i, J Ist, spi, M., Lesimple, S., Secchiari, A., Bosch, D., Montanini, A., Macera, P., and Davies, H.L. $\left(2 U_{c}{ }^{\Upsilon} C\right)$. The Eocene Subduction-Obduction Complex of New Caledonia. In: Maurizot P., and Mortirı. ’r, N. (ed.) New Caledonia: Geology, Geodynamic Evolution and Mineral Resources. Geolug ca / Society, London, Memoirs, 51, https://doi.org/10.1144/M51-201א. ?0

McElhinny, M. W. (1964) Sta -tical significance of the fold test in palaeomagnetism. Geophysical Journal Intern ttio, al, 8(3), 338-340. https://doi.org/10.1111/j.1365246X.1964.tb06300.x

McFadden P.L. and McElinny M.W. (1990). Classification of the reversal test in paleomagnetism, Geophys. J. Int., 103, 725-729. https://doi.org/10.1111/j.1365-246X.1990.tb05683.x

Meffre, S. (1995). The development of island-arc related ophiolites and sedimentary sequences in New Caledonia. PhD thesis, University of Sydney, Australia, 258 pp.

Meffre S., Crawford A.J., and Quilty P.J. (2006). Arc-continent collision forming a large island between New Caledonia and New Zealand in the Oligocene. ASEG 18th Geophysical Conference Melbourne 2006. ASEG Extended Abstracts https://doi.org/10.1071/ASEG2006ab111 
Menand T., Daniels K. A., and Benghiat P. (2010). Dyke propagation and sill formation in a compressive tectonic environment. Journal of Geophysical Research 115, B08201, https://doi.org/10.1029/2009JB006791

Mortimer N., Campbell H.J., Tulloch A.J., King P.R., Stagpoole V.M., Wood R.A., Rattenbury M.S., Sutherland R., Adams C.J., Collot J., and Seton M. (2017). Zealandia: Earth's Hidden Continent. GSA Today 27, 3, 27-35 https://doi.org/10.1130/GSATG321A.1

Nicolas, A. (1989). Structure of Ophiolites and Dynamics of Oceanic Lithosphere. Kluwer, Dordrecht, 367.

Patriat, M., Collot, J., Etienne, S., Poli, S., Clerc, C., Mortimer, N.. Pa 'tier, F. and Juan, C. (2018). New Caledonia obducted Peridotite Nappe, offshore extent and in ${ }_{1}$, lic $_{\text {; }}$ cions for obduction and postobduction processes. Tectonics, 37, 1-20, https://doi.org/10.1 12/2 )17TC004722

Pirard, C. and Spandler, C. (2017). The zircon record ' f hi६ h-pressure metasedimentary rocks of New Caledonia: Implications for regional tectonics of the sout.--west Pacific. Gondwana research, 46, 79-94, https://doi.org/10.1016/j.gr.2017.03.001

Potel S., Ferreiro Mählmann R., Stern V. B , Mullis J. and Frey M. (2006). Very low-grade metamorphic evolution of pelitic rocks 4 . -der hign-pressure/low temperature conditions, NW New Caledonia (SW Pacific). Journal of Petrc of ; 4, 5, 991-1015 https://doi.org/10.1093/petrology/ศ $\sin _{\perp}$

Prinzhofer, A. and Nicolas, ‘ ( +280$)$. The Bogota peninsula, New Caledonia: A possible oceanic transform fault. Journal of Geon ๙ 88, 387-398. https://doi.org/10.1086/628523

Quesnel B., Gautier H., Boulvais Ph., Cathelineau M., Maurizot P., Cluzel D., Ulrich M., Guillot S., Lesimple S., and Couteau L., (2013). Syn-tectonic, meteoric water-derived carbonation of the New Caledonia Peridotite Nappe. Geology, 41 (10), 1063-1066. https://doi.org/10.1130/G34531.1

Quesnel, B., Gautier, P., Cathelineau, M., Boulvais, P., Couteau, C. and Drouillet, M. (2016). The internal deformation of the Peridotite Nappe of New Caledonia: a structural study of serpentinebearing faults and shear zones in the Koniambo Massif. Journal of Structural Geology, 85, 51-67, https://doi.org/10.1016/j.jsg.2016.02.006

Rawling, T.J. (1998). Oscillating orogenesis and exhumation of high-pressure rocks in New Caledonia, SW Pacific. PhD Thesis, Department of Earth Sciences, Monash University, Melbourne Australia. 
Schellart W.P., Lister G.S., and Toy V.G. (2006). A Late Cretaceous and Cenozoic reconstruction of the Southwest Pacific region: Tectonics controlled by subduction and slab rollback processes. Earth-Science Reviews 76 : 191-233 https://doi.org/10.1016/j.earscirev.2006.01.002

Schellart W.P. and Spakman W. (2012). Mantle constraints on the plate tectonic evolution of the Tonga-Kermadec-Hikurangi subduction zone and the South Fiji Basin region. Australian Journal of Earth Sciences 59, 6, 933-952. https://doi.org/10.1080/08120099.2012.679692

Sécher, D. (1981). Les Iherzolites ophiolitiques de Nouvelle-Calédonie et leurs gisements de chromite. Ph D. thesis, Université de Nantes, France, 228.

Sevin B., Ricordel-Prognon C., Quesnel F., Cluzel D., and Maurizot r. (2012). First paleomagnetic dating of ferricrete in New Caledonia: new insight on the morphog nes $s$ and paleoweathering of 'Grande Terre'. Terra Nova 24, 77-85. https://doi.org/10.1111/, 136 j-3121.2011.01041.x

Soret, M., Agard, P., Dubacq, B., Vitale-Brovarone, A Mo iié, P., Chauvet, A., Whitechurch, H., and Villemant, B. (2016). Strain localization and fluid infi!. ratic. in the mantle wedge during subduction initiation: Evidence from the base of the "ev Caledonia ophiolite, Lithos 244, 1-19. https://doi.org/10.1016/j.lithos.2015.11.022

Spandler, C., Hermann, J., Arculus, I. and Mavrogenes, J.A. (2003). Redistribution of trace elements during prograde metamorphi $m{ }^{c^{\prime}}$ rorn lawsonite blueschist to eclogite facies; implications for deep subduction-zone processes. c.nu ıbution to Mineralogy and Petrology, 146, 205-222. https://doi.org/10.1007/s00410- 33-し:995-5

Spandler, C., Hermann, 1. . . d Alus, R. and Mavrogenes, J. (2004). Geochemical heterogeneity and element mobility $i_{1}$. Je $n l v$ jubducted oceanic crust; insights from high-pressure mafic rocks from New Caledonia. Chemi ial Geology 206, 21-42. https://doi.org/10.1016/j.chemgeo.2004.01.006

Spandler C., Rubatto D. and Hermann J. (2005). Late Cretaceous-Tertiary tectonics of the southwest Pacific: Insights from U-Pb sensitive, high-resolution ion microprobe (SHRIMP) dating of eclogite facies rocks from New Caledonia. Tectonics 24, TC3003, https://doi.org/10.1029/2004TC001709

Tarling, D. H. (1967). Results of a paleomagnetic reconnaissance of the New Hebrides and New Caledonia. Tectonophysics 4: 55-68. https://doi.org/10.1016/0040-1951(67)90058-3

Théveniaut H., Prognon C., and Delor C. (2017). Construction d'une courbe de dérive apparente des poles (CDAP) de Nouvelle Calédonie. Rapport final. BRGM/RP-67339-FR 
Teyssier, C., Chatzaras, V. and Von Der Handt, A. (2016). Microfabrics in depleted mantle plaeotransform (New Caledonia). Geophysical Research Abstracts, European Geoscience Union, EGU2016-11489, 18.

Titus, S.J., Maes, S.M., Benford, B., Ferre, E.C. and Tikoff, B. (2011). Fabric development in the mantle section of a paleotransform fault and its effect on ophiolite obduction, New Caledonia. Lithosphere 3, 221-244, https://doi.org/10.1130/I122.1

Uruski C. and Wood R. (1991). A new look at the New Caledonia Basin, an extension of the Taranaki Basin, offshore North Island, New Zealand. Marine and Petroleum Geology 8, 4, 379-391. https://doi.org/10.1016/0264-8172(91)90061-5

Van de Beuque S. (1999). Evolution géologique du domaine pt -i-c: lédonien (sud-ouest Pacifique). PhD thesis Université de Bretagne occidentale, Fran @ 9 , 2 pp.

Van de Lagemaat S. H. A., van Hinsbergen D. J. J., Bor chm n L. M., Kamp P. J. J., and Spakman W. (2018). Southwest Pacific absolute plate kinematic recor.strucion reveals major Cenozoic TongaKermadec slab dragging. Tectonics 37, 8, 2647-2674 itt ss://doi.org/10.1029/2017TC004901

Vitale Brovarone, A., and Agard, P. (20, 2). . rue metamorphic isograds or tectonically sliced metamorphic sequence? New high-spati: 1 resolunion petrological data for the New Caledonia case study. Contributions to Mineralogy and pt: rology, 166 (2), 451-469.

https://doi.org/10.1007/s00410-01?- -?९s-2

Vitale Brovarone A., Agard ? , 's'onié P., Chauvet A., and Rabaute A., (2017). Tectonometamorphic architecture of thr ${ }^{\prime}$ 'P belt of New Caledonia. Earth Science Reviews 168, 48-67. https://doi.org/10.101し,'i...rss rev.2018.01.006

Vogt, J. and Podvin, P. (1983). Carte Géologique à l'échelle du 1 / 50000 et notice explicative: feuille Humboldt-Port-Bouquet. Territoire de Nouvelle-Calédonie - Bureau de Recherches Géologiques et Minières, 1-68.

Wenner, D.B., Taylor, H.P. Jr. (1971). Temperatures of serpentinization of ultramafic rocks based on $\mathrm{O}^{18} / \mathrm{O}^{16}$ fractionation between coexisting serpentine and magnetite. Contrib. Mineral. Petrol. 32, 165-185. https://doi.org/10.1007/BF00643332

Whattam, S. A. (2008). Arc-continent collisional orogenesis in the SW Pacific and the nature, source and correlation of emplaced ophiolitic nappe components, Lithos 113, 1-2, 88-114. https://doi.org/10.1016/j.lithos.2008.11.009 


\section{Figure captions}

Figure 1: Geological sketch map of New Caledonia restricted to the geological units addressed in this article. Abbreviations in main map: BSZ Belep Shear Zone; BTF Bogota Transform Fault; HC Humboldt Corridor. Inset, color chart; dark red: continental crust, light red: thinned continental crust, light blue: oceanic crust, dark blue: oceanic plateau; abbreviations, LHR : Lord Howe Rise, NR : Norfolk (New Caledonia) Ridge, LR : Loyalty Ridge, HP : Hikurangi Plateau.

Figure 2: Non-sheared coarse-grained diorite dykes and sills crosscutting deeply serpentinised harburgite to exemplify magma injection in an already fractured rock. The dotted lines represent the attitude of the gently dipping mantle fabric of the peridotite. Ore $\mathrm{dr}_{y}{ }^{\prime}$ ' $g$ area, western bottom of the Tiebaghi Massif (164.20344; -20.48416).

Figure 3: Non-sheared lower Eocene dykes (Massif du Sud, · (a) leucogabbro dyke at the confluence of Napouéredjeine and Pirogues rivers (166.73? 1 ; ?.2.20831) ; (b) hornblende-gabbro pegmatoid dyke crosscutting a pyroxenite body, Plum Pass ' of (b) to show fragmented amphibole crystals coate 10 'injected' by plagioclase (lens cap size is 6 $\mathrm{cm})$.

Figure 4: Non-sheared hornblende leucog ' hbro dyke crosscutting pyroxenite, Plum Pass (166.67156; -22.30200); (b) sheared leucog hbro with c and s shear structures at the walls and transposed c-s mylonitic foliation at the cen :re (Plum Pass); (166.67233; -22.30285); (c) and (d) detailed views of the central myloni a shuwing amphibole and orthopyroxene rotated porphyroclasts. All shear indicai rs, re consistent with reverse-sinistral, top-to-the-NW motion.

Figure 5: (a) Internal f Ids ' $n$ a layered gabbro dyke of Ouen Island (166.80956; -22.41200); (b) detailed view of the forme. showing extremely sharp fold hinges. The white arrow points to an anthophyllite reaction rim around an eroded peridotite xenolith; (c) partly disrupted flow fold structure in a weathered felsic sill, Ouen Island (166.80783; -22.41255); (d) sheared and foliated dyke (yellow arrows) injected by en-echelon leucogabbro lenses (white arrows), the foliated part of the dyke shows sinistral motion (strike N145E), ancient chromite mine Georges Piles (166.75567; 22.24885).

Figure 6: Plot of orientations of lower Eocene dykes and sills from the Peridotite Nappe at island scale (Schmidt equiaerial stereonet, lower hemisphere). Bold circles represent sheared dykes (with sense of shear). 
Figure 7: (a) Dolerite lensoids within a serpentinised normal fault (Kopeto Massif); (b) detailed view of the fault zone to show the c-s structure with down-dip motion.

Figure 8: (a) Antigorite crack seal on a small dextral fault (offset $<10 \mathrm{~cm}$ ); (b) tremolite-bearing crack seal (photo credit: Lahondère, 2012).

Figure 9: (a) Plot and kinematic analysis of antigorite and tremolite-antigorite-bearing small faults (main axes of the strain ellipsoid: $X=$ stretching, $Y$ intermediate, $Z$ shortening). Note that the majority of mineral fibers indicate strike slip or oblique slip motion. The insert (b) illustrates the permutation of the main strain axes $(X / Y$ and $Y / Z)$. The strain ellipsoid axes have been computed with the FaultKin application (Allmendinger et al., 2012), (Schmidt equiat. ${ }^{i}{ }_{1} l$ stereonet, lower hemisphere).

Figure 10: A typical outcrop of Poya Terrane Basalts to sho v te tonically interleaved upright basalt (bas) and abyssal argillite (arg) slices, the whole set … s s '.'eared toward the SW and developed some schistosity beneath the Peridotite Nappe $i^{\text {Tr }} .34$ track); (165.27649; -21.47172$)$.

Figure 11: Tectonic map of the Poya Terrane +o "10 / the regional-scale " $Z$ " type folds with vertical axes consistent with dextral transpre, sic ר. $\mathrm{l}$ : $s$ worth to note that PTB and KF display the same large-scale structure while the underlyin ${ }_{\delta}$ эutochthonous/parautochthonous units display a much simpler organization (blue line).

Figure 12: Formation and struct ur o c che Poya Terrane in a three-step model of intra-oceanic accretion and oblique subductior obaı.ction. KF: Kone Facies (turbidites); PTB: Poya Terrane Basalts. Blue: oceanic crust, green: upner $\mathrm{r}$, antle peridotites, orange: continental crust.

Figure 13: (a) Tect nic nar, of the Eocene HP-LT belt of northern New Caledonia. The blue lines show the orientation of regi snal structures (foliation, bedding, serpentinite or melange slices). Bold black lines represent the trend of structures when they can be traced over long distances $(>20 \mathrm{~km})$. Large-scale " $Z$ " type folds appear in high-grade part of the metamorphic domain. It is worth to note the southwestward decrease of the folds closure and southeastward changing style from open fold into fault-fold. (b) cartoon showing the relationship of " $\mathrm{Z}$ " type folds and regional-scale transpression. (c) structural map of the restored orientation of the stretching lineation.

Figure 14: Equal-area projection of directions from Characteristic Remanence Magnetization (ChRM). a. directions in-situ coordinates; b. directions in bedding corrected coordinates.

Figure 15: Paleomagnetic poles from this study and Dallanave et al. (2020) with the Australian APWP (Besse and Courtillot, 2002, 2003) 
Figure 16: Attempted paleogeographic reconstruction of the Southwest Pacific during the Eocene to account for: (a) lower Eocene subduction inception at or near a RRR triple junction, (b) oblique pre-obduction subduction; (c) subduction jamming by the Norfolk Ridge and counterclockwise rotation of New Caledonia; and (d) final blocking of the subduction in New Caledonia by the Lord Howe Rise; meanwhile, the subduction continued to the south (modified from Cluzel et al., 2001, 2012a; Meffre et al., 2006; Patriat et al., 2018). (NC: New Caledonia, NR: Norfolk Ridge, LHR: Lord Howe Rise, NLB: North Loyalty Basin, AUSTR: Australia, V: Vanuatu, T: Tonga, K: Kermadec, gray bold line: active spreading ridge, dark blue bold line: extinct spreading ridge.

Table 1: Paleomagnetic results from southern New Caledonia. $r / \mathrm{N}, \mathrm{D}, \mathrm{l}, \alpha, \mathrm{g}$ and $\mathrm{s}$ stand for statistic/total measured samples, declination, inclination cone radius c' statistic confidence at $95 \%$, in-situ, bedding-corrected coordinates, respectively.

Table 2: Comparison of paleomagnetic results from $\wedge$ ew -aledonia with Australian APWP. $\lambda$ and $\phi$ stand for latitude and longitude of paleomagnetic pole resp ctively; $\mathrm{dp}, \mathrm{dm}$ and $\mathrm{A}_{95}$ stand for statistic errors in latitude and rotation at $95 \%$ confic s icf level. Australian poles are from Besse and Courtillot $(2002,2003)$. Differences are calcu' $d \tau t$ ta $21.8^{\circ} \mathrm{N}, 165.9^{\circ} \mathrm{E}$ (average of geographic coordinates of sites $A, B, E, F)$. Error bars are cu rulated by $\left(0.63^{*}\right)$ root $\left(A_{95}{ }^{2}+D_{p}\right.$ or $\left.m^{2}\right)$ (Demarest, 1983).

Table 3: Summary of tectonic ff au ' $r_{\epsilon}$, deduced from the structural analysis of the Poya Terrane, Peridotite Nappe and Eocene me ${ }^{+}$mo. phic belt. All kinematic axes have been computed in the present orientation of the island a. $\mathrm{f}$ do not account for $\sim 60^{\circ}$ counterclockwise rotation. 


\begin{tabular}{|c|c|c|c|c|c|c|c|c|c|c|c|c|}
\hline Site & location & Formation & Lithology & Age & $\mathrm{n} / \mathrm{N}$ & $\begin{array}{r}\text { Sam } \\
\text { coorc }\end{array}$ & ling & & Pal & $\overline{\operatorname{magn}}$ & ic direc & \\
\hline & & & & $\mathrm{Ma}$ & & $\begin{array}{l}\text { Lat. } \\
\left({ }^{\circ} \mathrm{N}\right)\end{array}$ & $\begin{array}{l}\text { Long. } \\
\left({ }^{\circ} \mathrm{E}\right)\end{array}$ & $\begin{array}{l}\text { Dg } \\
\left({ }^{\circ}\right)\end{array}$ & $\begin{array}{l}\text { Ig } \\
\left({ }^{\circ}\right)\end{array}$ & $\begin{array}{c}\alpha_{95 g} \\
\left({ }^{\circ}\right)\end{array}$ & $\begin{array}{l}\text { Ds } \\
\left({ }^{\circ}\right)\end{array}$ & $\begin{array}{l}\text { Is } \\
\left({ }^{\circ}\right)\end{array}$ \\
\hline A & $\begin{array}{l}\text { Gadji Bay } \\
\text { (Dumbea) }\end{array}$ & $\begin{array}{l}\text { Bourail } \\
\text { Flysch }\end{array}$ & siltstone & $\sim 35$ & $6 / 11$ & -22.20 & 166.35 & 338.7 & -44.5 & 19.6 & 358.8 & -33 \\
\hline E & $\begin{array}{l}\text { Nessadiou, } \\
\text { RT1, Cimetière } \\
\text { des Arabes }\end{array}$ & $\begin{array}{l}\text { Bourail } \\
\text { Flysch }\end{array}$ & $\begin{array}{l}\text { Fine grained } \\
\text { sandstone }\end{array}$ & $\sim 35$ & $4 / 6$ & -21.62 & 165.55 & 355.7 & -8.3 & 25.2 & 349.6 & -38 \\
\hline $\mathrm{F}$ & $\begin{array}{c}\text { Roche Percée, } \\
\text { Bourail }\end{array}$ & $\begin{array}{c}\text { Priabonian } \\
\text { Bourail } \\
\text { Flysch }\end{array}$ & siltstone & $\sim 35$ & $4 / 7$ & -21.61 & 165.46 & 326.9 & -34.4 & 23.9 & 322.2 & -37 \\
\hline G & Col Aymes & $\begin{array}{c}\text { Lutetian } \\
\text { Bourail } \\
\text { Flysch }\end{array}$ & $\begin{array}{l}\text { Calcareous } \\
\text { sandstone }\end{array}$ & $\sim 42$ & $0 / 4$ & -2167 & 165.55 & \multicolumn{5}{|c|}{ No stable ChRM isolable } \\
\hline $\mathrm{H}$ & Tontouta River & $\begin{array}{l}\text { lower } \\
\text { Eocene }\end{array}$ & Dolerite & $\sim 50$ & $0 / 7$ & $? 1 . y<$ & 166.33 & \multicolumn{5}{|c|}{ No stable ChRM isolable } \\
\hline$A E F$ & & & & $\sim 35$ & $\begin{array}{c}14 / \\
1\end{array}$ & $-\angle 1.90$ & 165.95 & 341.1 & -31.8 & 14.0 & 345.9 & -36 \\
\hline
\end{tabular}

Table 1. Paleomagnetic results from southern New Caledon a

$\mathrm{n} / \mathrm{N}, \mathrm{D}, \mathrm{I}, \alpha, \mathrm{g}$ and s stand for statistic/total measurec sa $n r$. es, declination, inclination cone radius of statistic confidence at 95\%, in-situ, bedding-cor _ tec oordinates, respectively. 
Au niveau des sites, les statistiques sont moins bonnes après corrections de pendage par rapport avant corrections, mais les moyennes en âge change la tone. 


\begin{tabular}{|c|c|c|c|c|c|c|c|c|c|c|}
\hline \multirow{3}{*}{$\begin{array}{c}\text { Age } \\
35 \mathrm{Ma}\end{array}$} & \multicolumn{4}{|c|}{ New Caledonia Pole } & \multicolumn{3}{|c|}{ Australian Pole } & \multirow{3}{*}{$\begin{array}{c}\begin{array}{c}\text { Difference } \\
\text { in latitude } \\
\left({ }^{\circ}\right)\end{array} \\
-8.9 \pm 6.1\end{array}$} & \multirow{3}{*}{$\begin{array}{c}\begin{array}{c}\text { Difference } \\
\text { in rotation } \\
\left({ }^{\circ}\right)\end{array} \\
-31.2 \pm 9.6\end{array}$} & \multirow{3}{*}{$\begin{array}{l}\text { Refer } \\
\text { This : }\end{array}$} \\
\hline & $\lambda$ & $\phi$ & & $\mathrm{m}$ & $\lambda$ & $\begin{array}{l}\phi \\
\left(^{\circ}\right)\end{array}$ & $\mathrm{A}_{95}$ & & & \\
\hline & 76.8 & 79.7 & 8.5 & 14.6 & 72.9 & 285.3 & 4.5 & & & \\
\hline $45 \mathrm{Ma}$ & 50.5 & 29.0 & 4.2 & 5.3 & 70.2 & 294.6 & 5.4 & $11.7 \pm 4.3$ & $-56.2 \pm 4.8$ & $\begin{array}{r}\text { Dall } \\
\text { al }\end{array}$ \\
\hline
\end{tabular}

Table 2. Comparison of paleomagnetic results from New Caledonia with Australian APWP

$\lambda$ and $\phi$ stand for latitude and longitude of paleomagnetic pole, respectively; $\mathrm{dp}, \mathrm{dm}$ and $\mathrm{A}_{95}$ stand for statistic

errors in latitude and rotation at 95\% confidence level. Australı. $n \mathrm{p}$ sles are from Besse and Courtillot $(2002,2003)$.

Differences are calculated at $-21.8^{\circ} \mathrm{N}, 165.9^{\circ} \mathrm{E}$ (average of o voraphic coordinates of sites $\mathrm{A}, \mathrm{B}, \mathrm{E}$, F).

Error bars are calculated by $\left(0.63^{*}\right) \operatorname{root}\left(\mathrm{A}_{95^{2}}+\mathrm{D}_{\mathrm{p} \boldsymbol{\prime}} \mathrm{n}^{2}\right)$ (Demarest, 1983). 


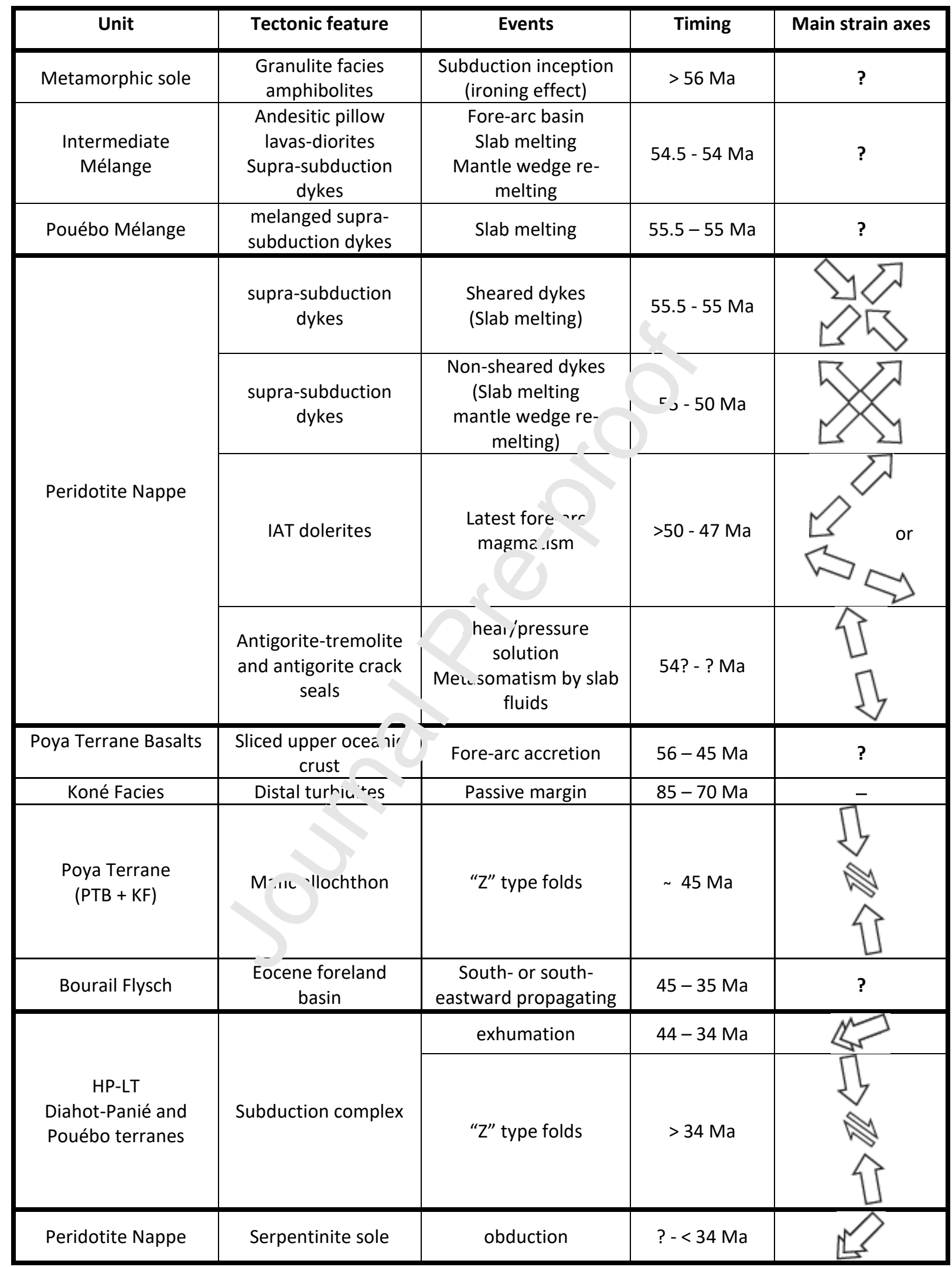

Table 2: Summary of tectonic features deduced from the structural analysis of the Poya Terrane, Peridotite Nappe and Eocene metamorphic belt. All kinematic axes have been computed in the present orientation of the island and do not account for counterclockwise rotation. 
Highlights

- The structural analysis of the Eocene subduction-obduction complex of New Caledonia reveals a polyphase evolution

- Paleomagnetic data from autochthonous terranes record $c a 56^{\circ}$ counterclockwise rotation during the mid- to late Eocene

- The upper plate represented by the ultramafic fore-arc allochthon underwent oblique-slip dominated dilatational tectonics associated with northward subduction in rapidly cooling conditions

- The allochthonous Poya Terrane and metamorphic units of the HP-LT belt display Z-type folds due to dextral shearing prior to final tectonic emplacement

- Finally, ultramafic rocks were obducted with top-to-the-SW kinematics 


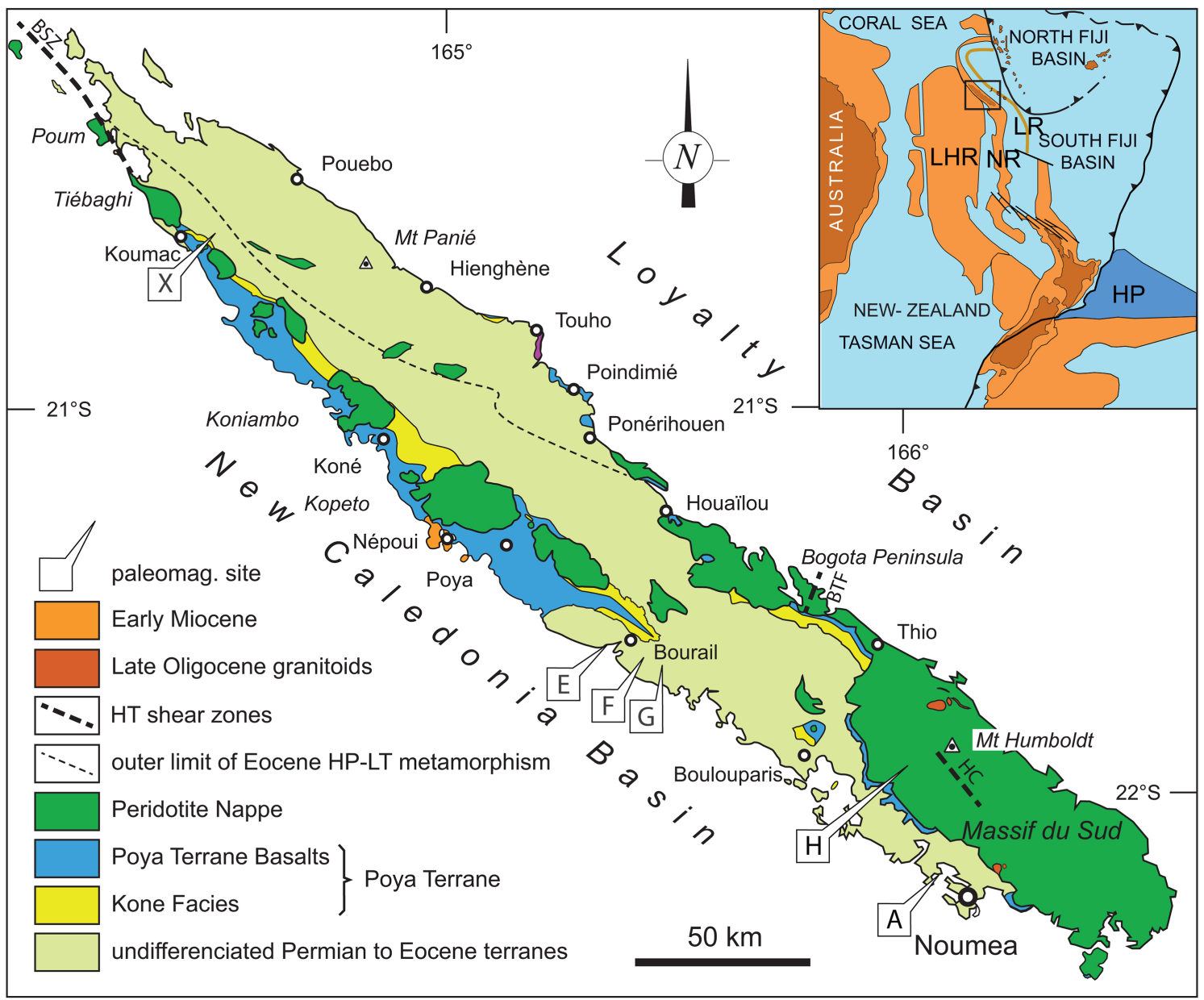

Figure 1 


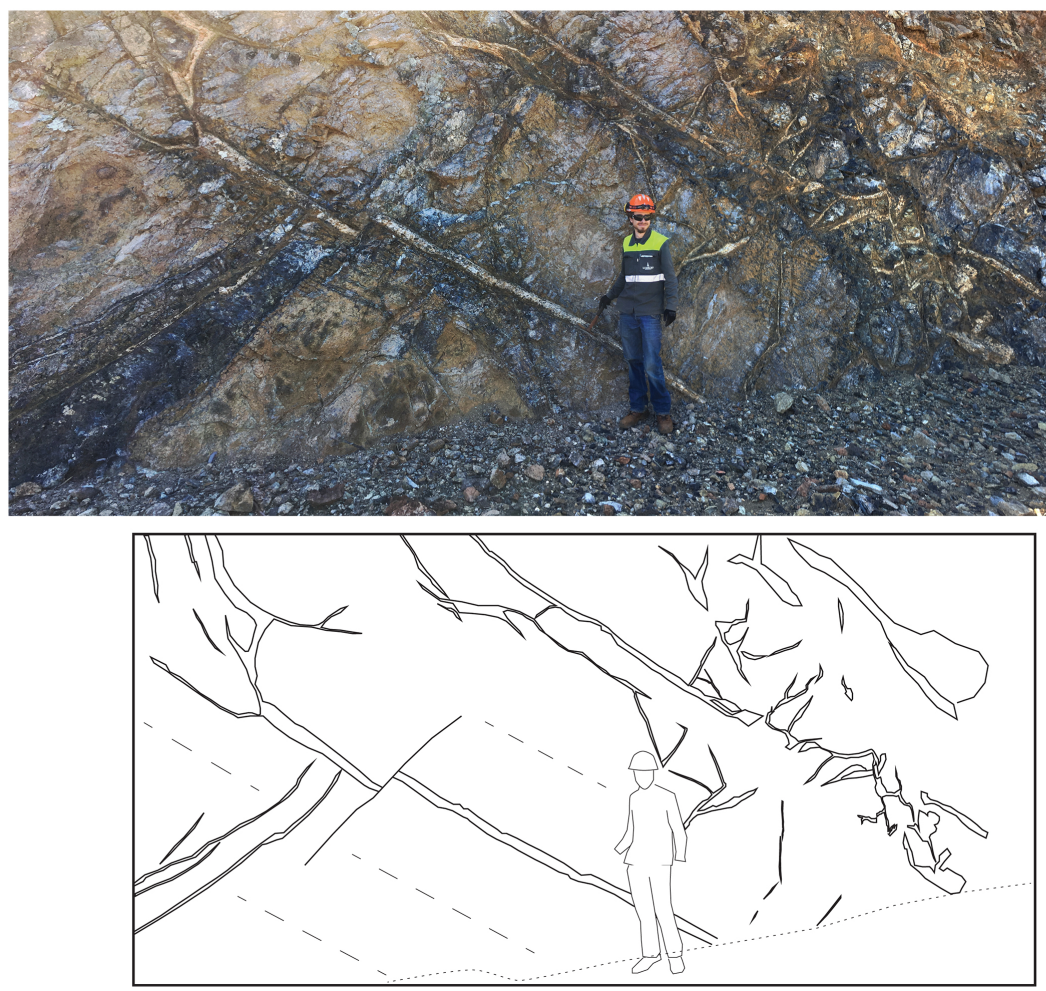

Figure 2 

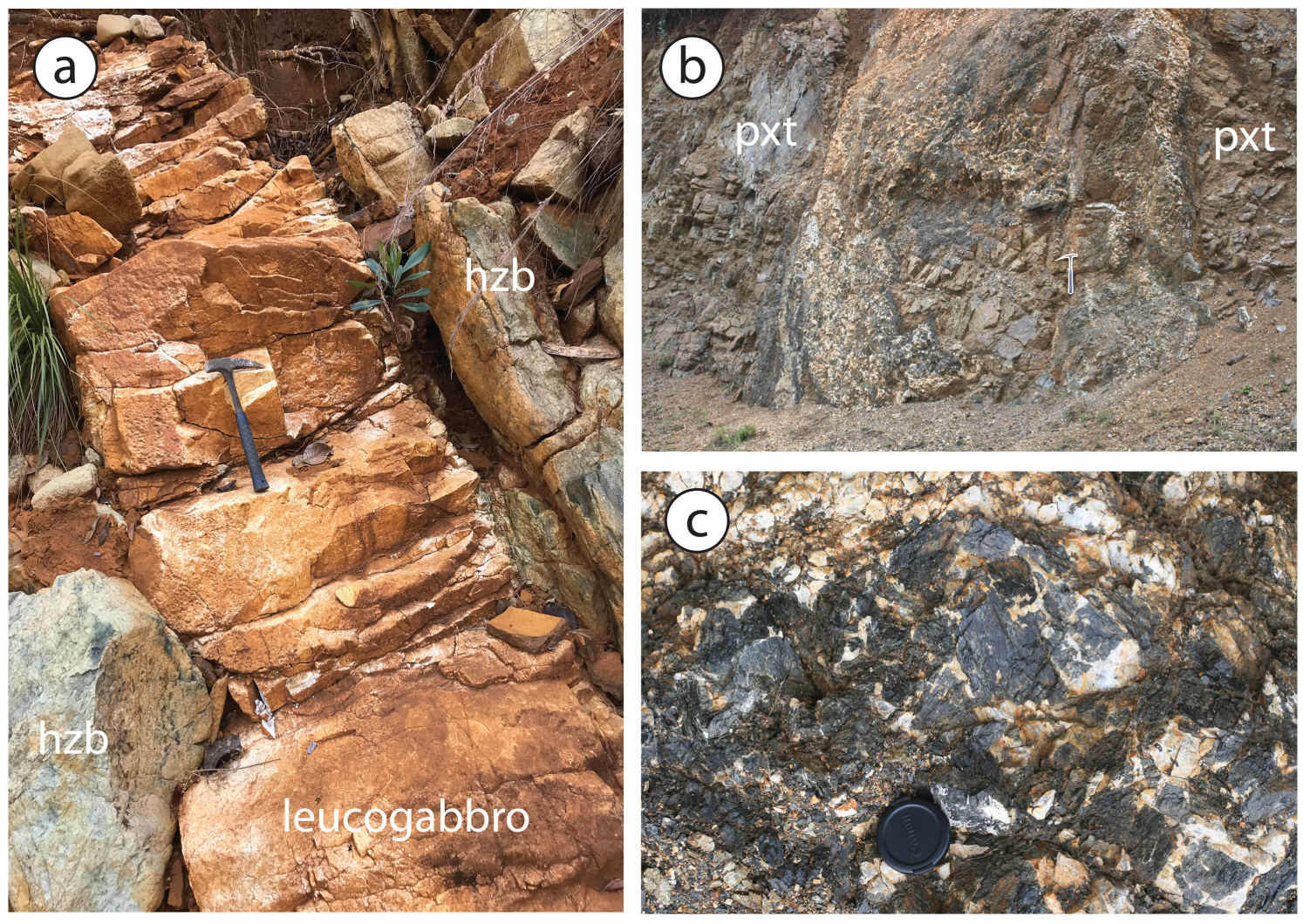

Figure 3 

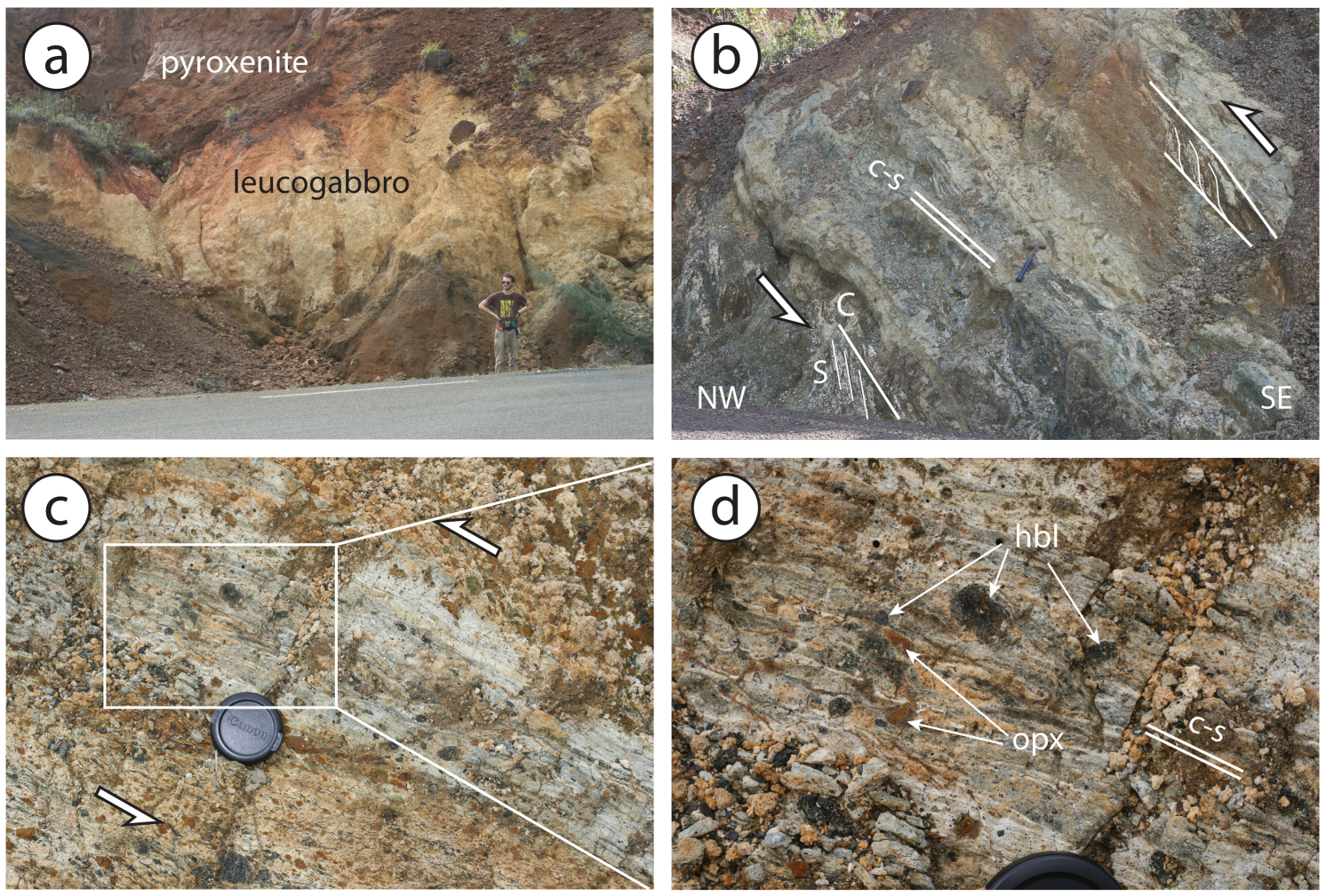

Figure 4 

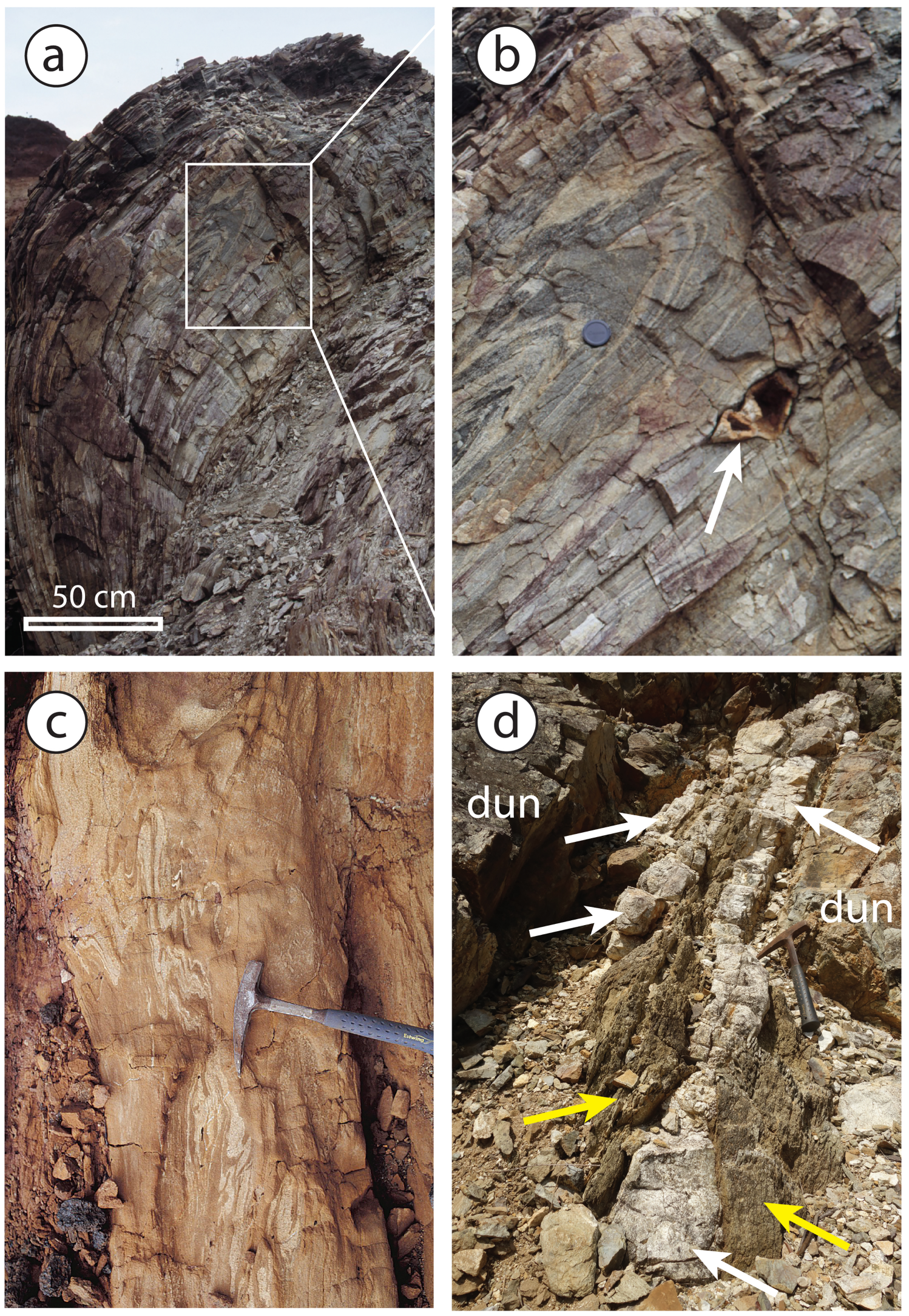

Figure 5 


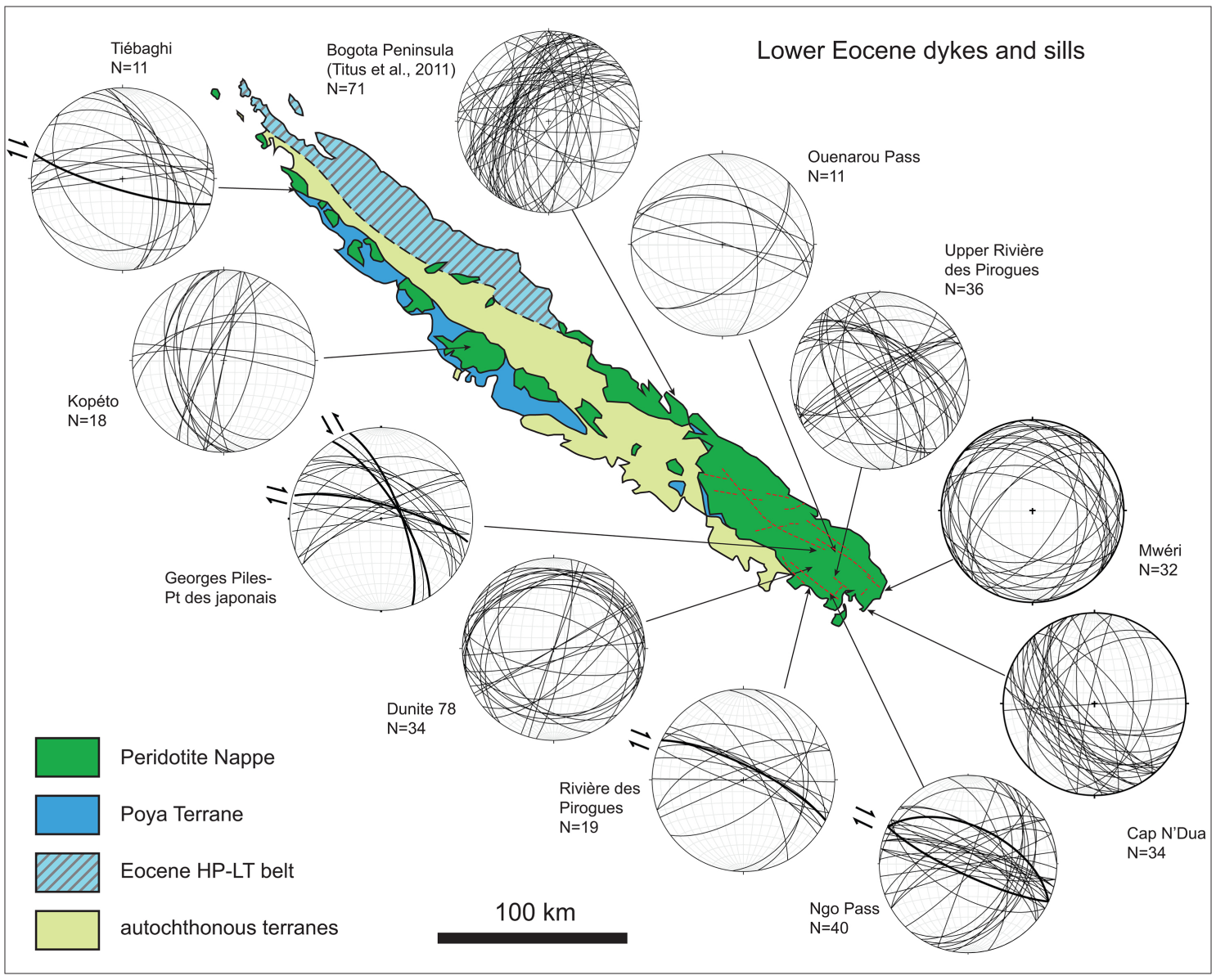

Figure 6 


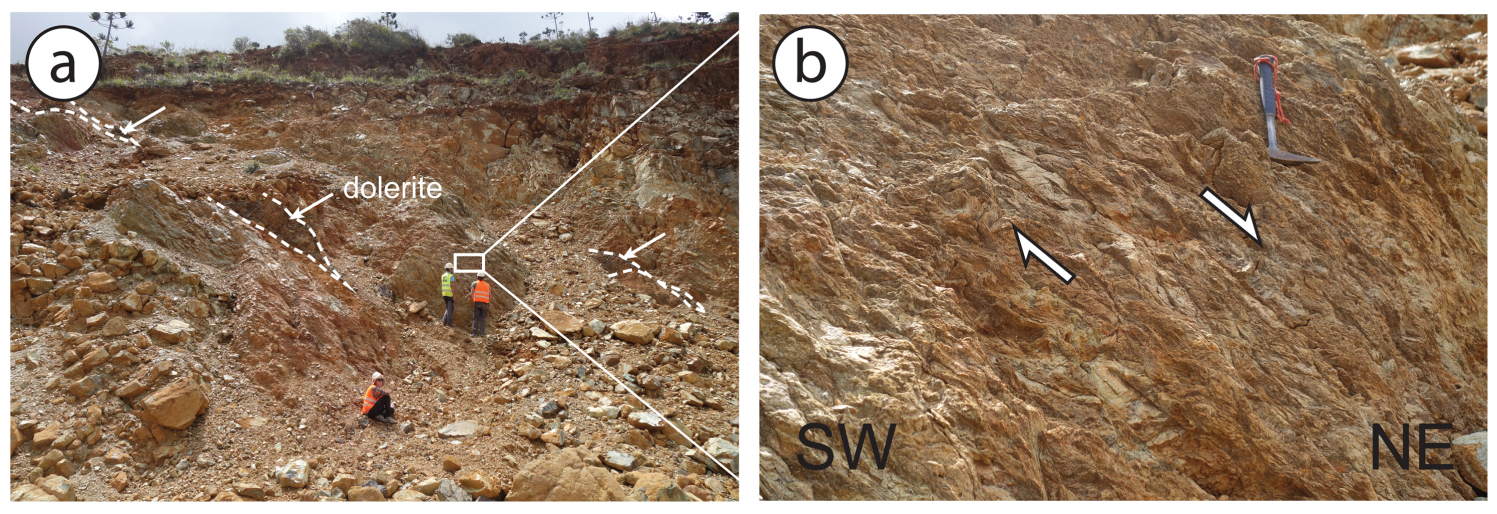

Figure 7 

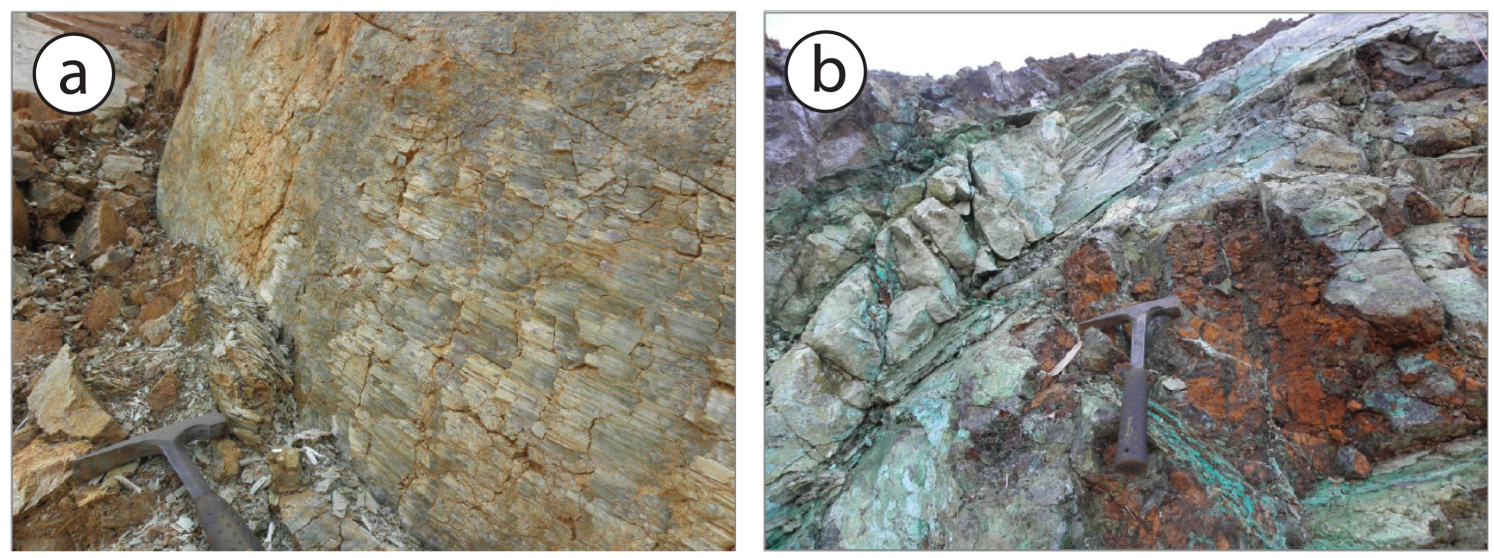

Figure 8 


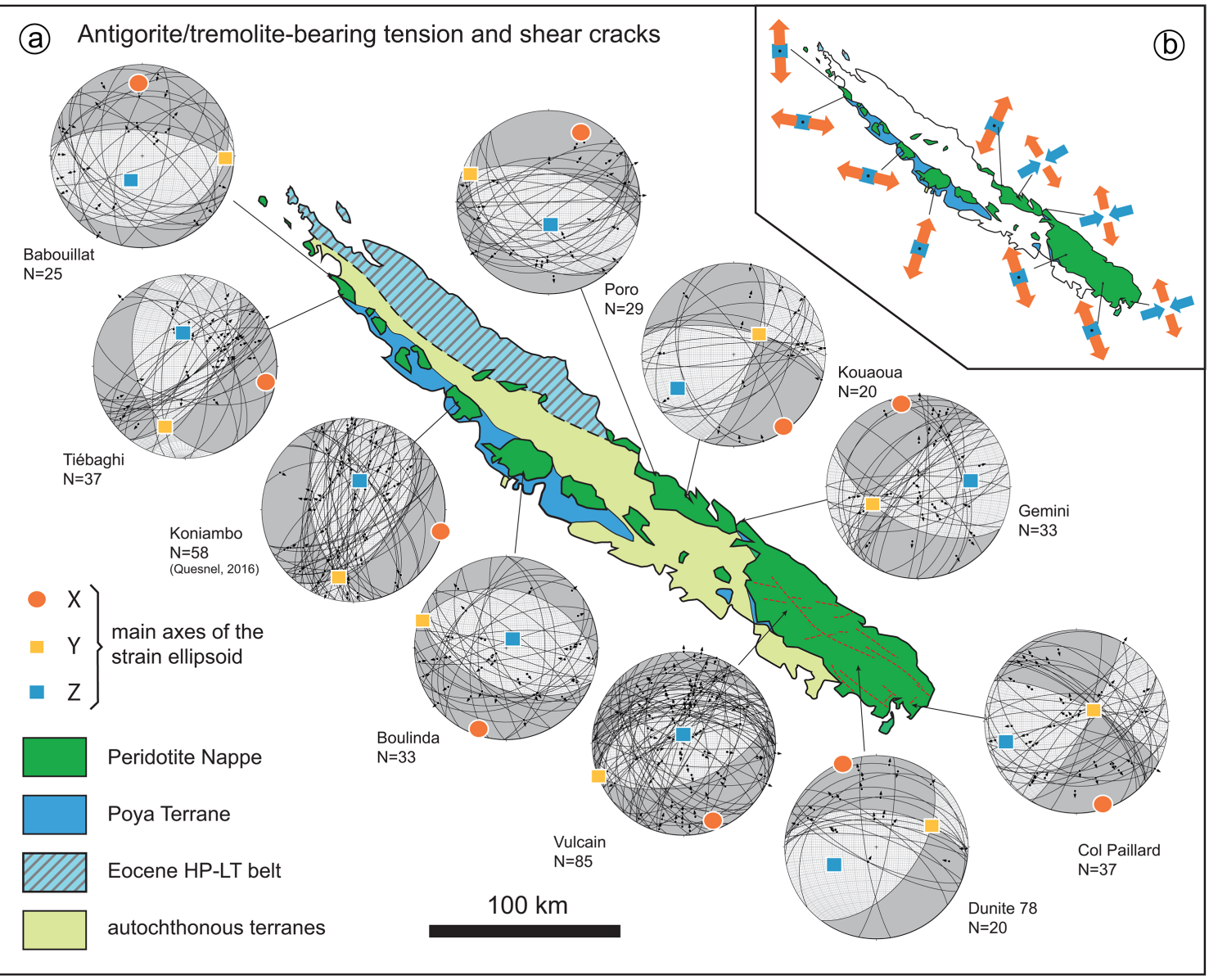

Figure 9 
NE

bas $3+3 y^{4}$, farg

The

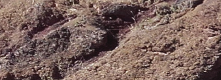

2.7. bas.t.

6. 250

(1) $1+e^{2}$

7).

(1. $+3 y^{2}$ bas

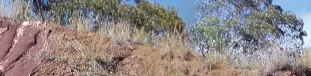

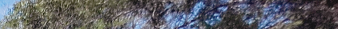
- s - St S SW 3ri. $+x^{2}$ 


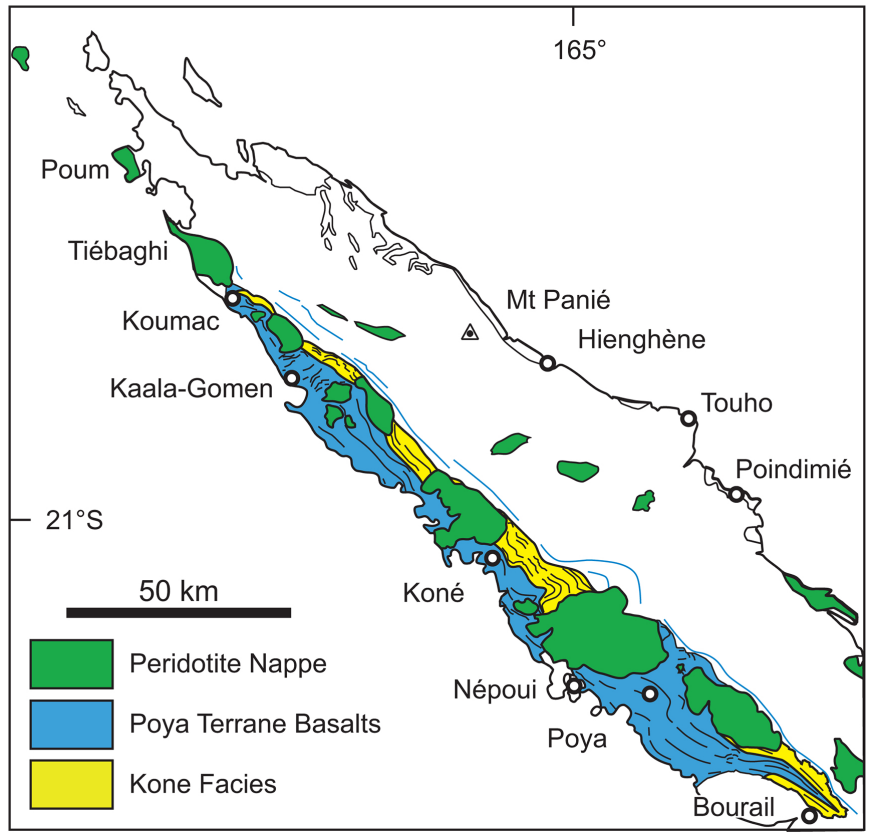

Figure 11 


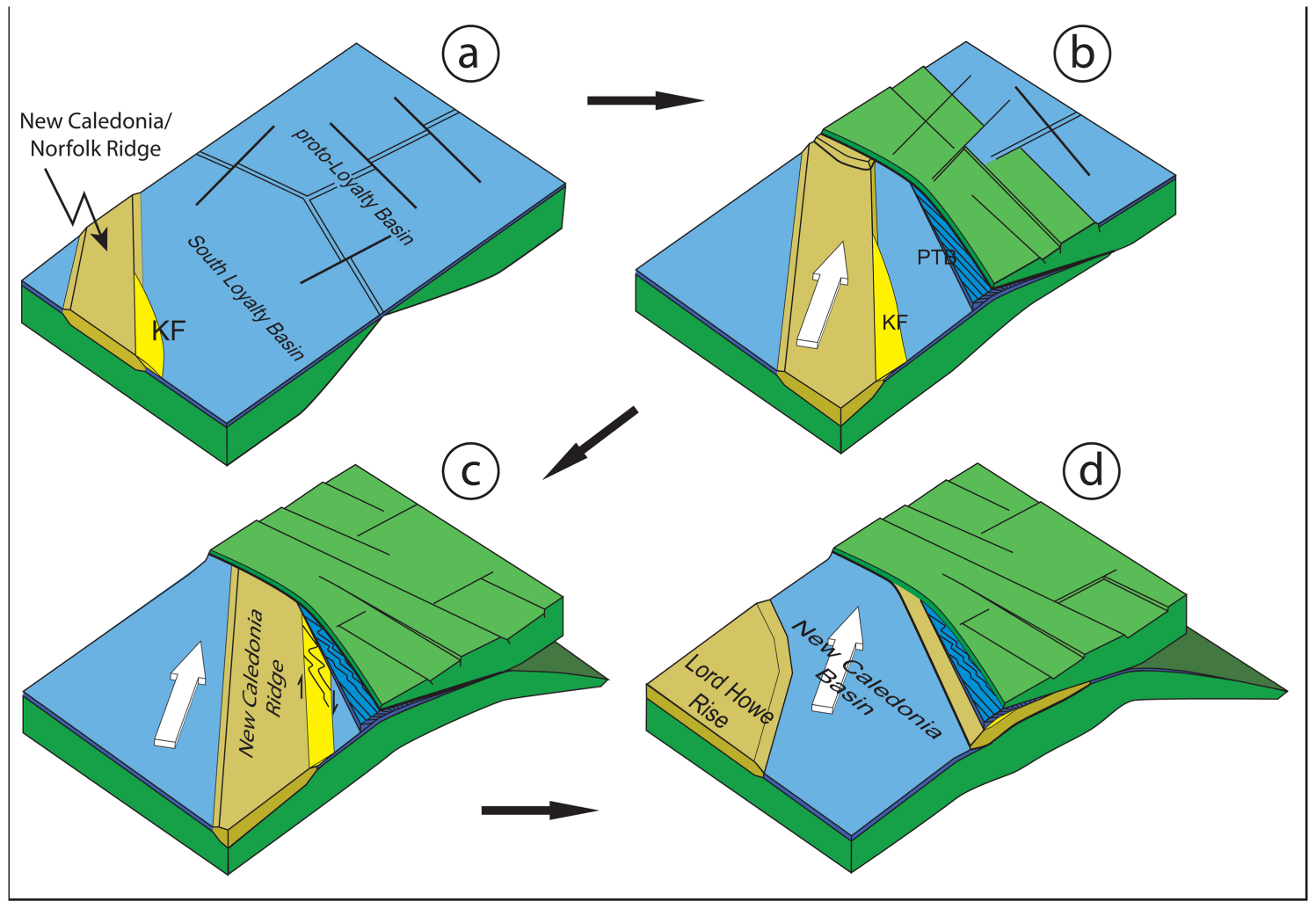

Figure 12 


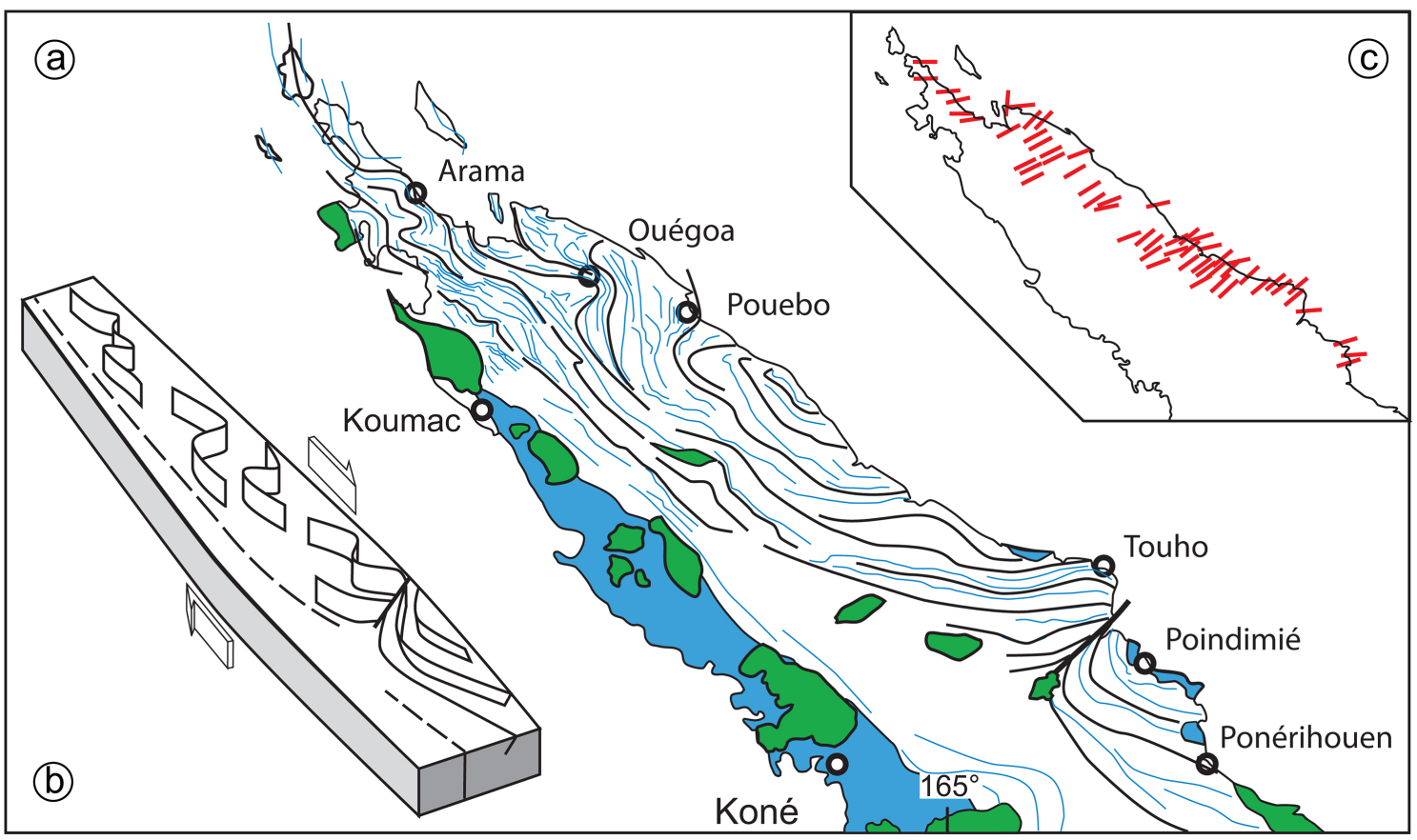

Figure 13 

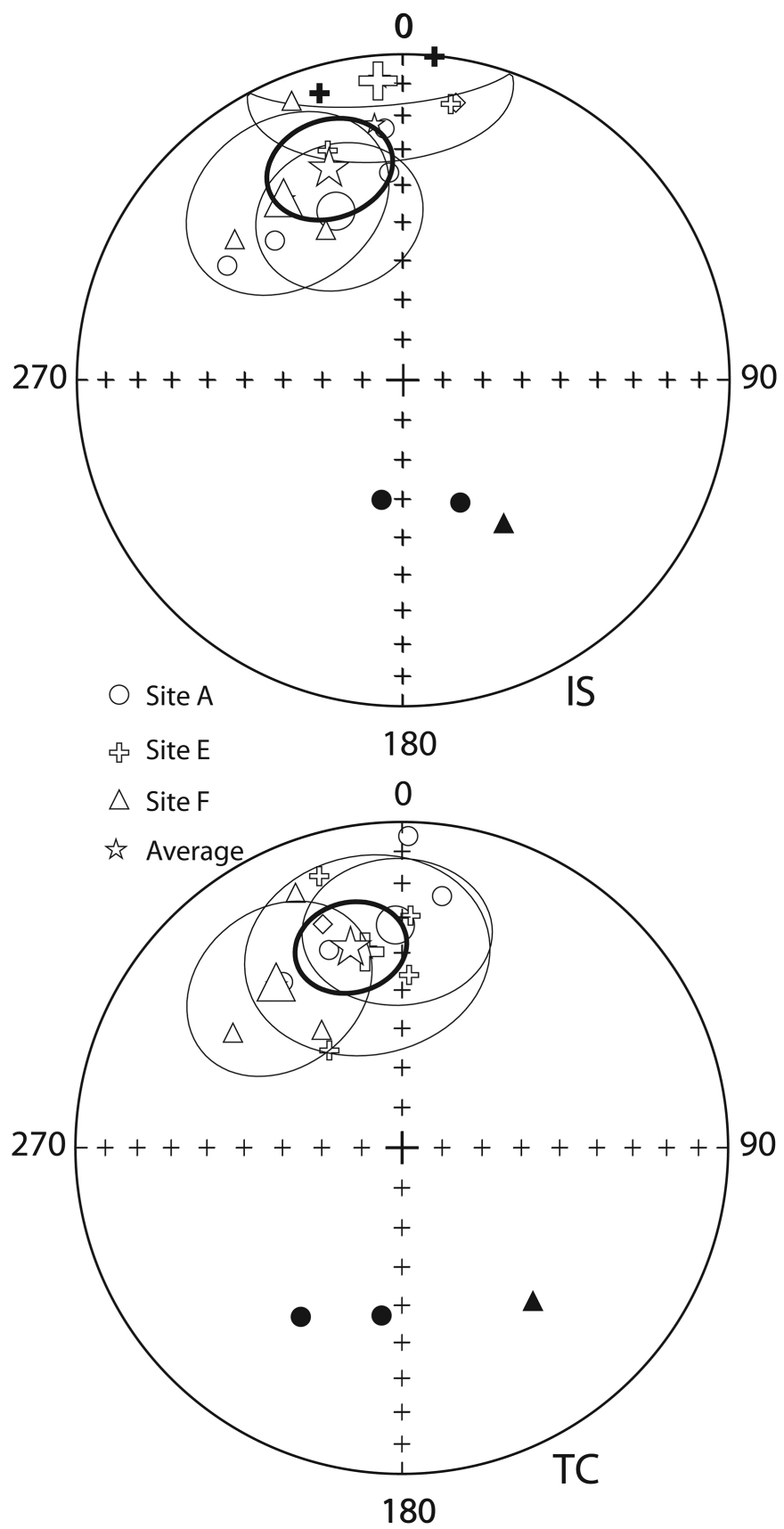

Figure 14 


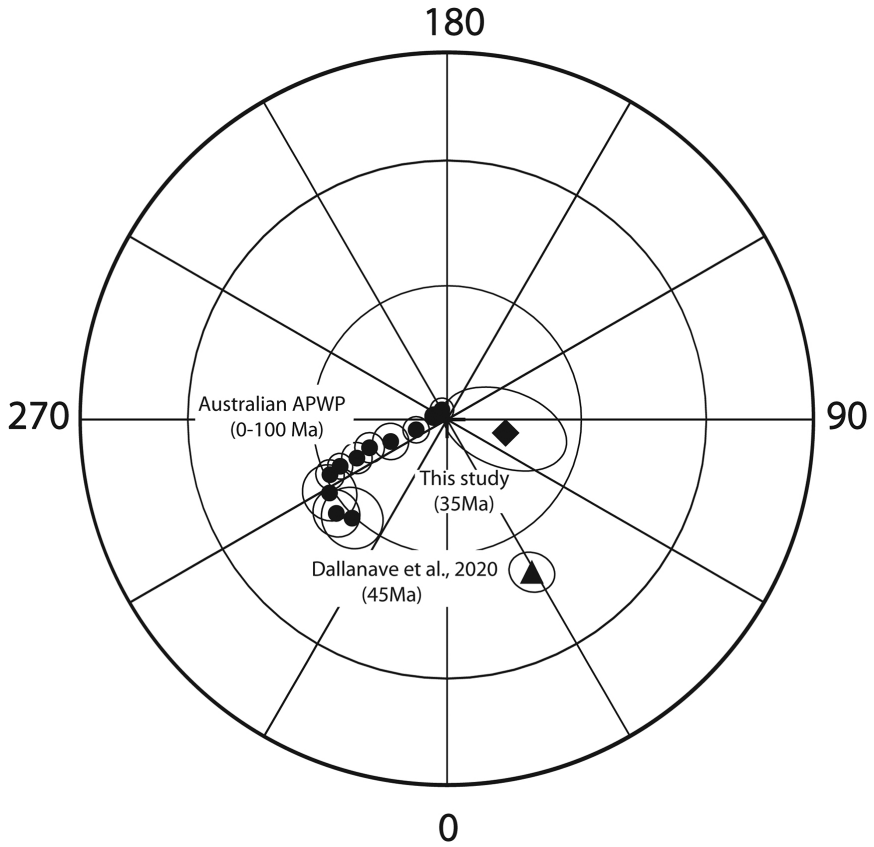

Figure 15 

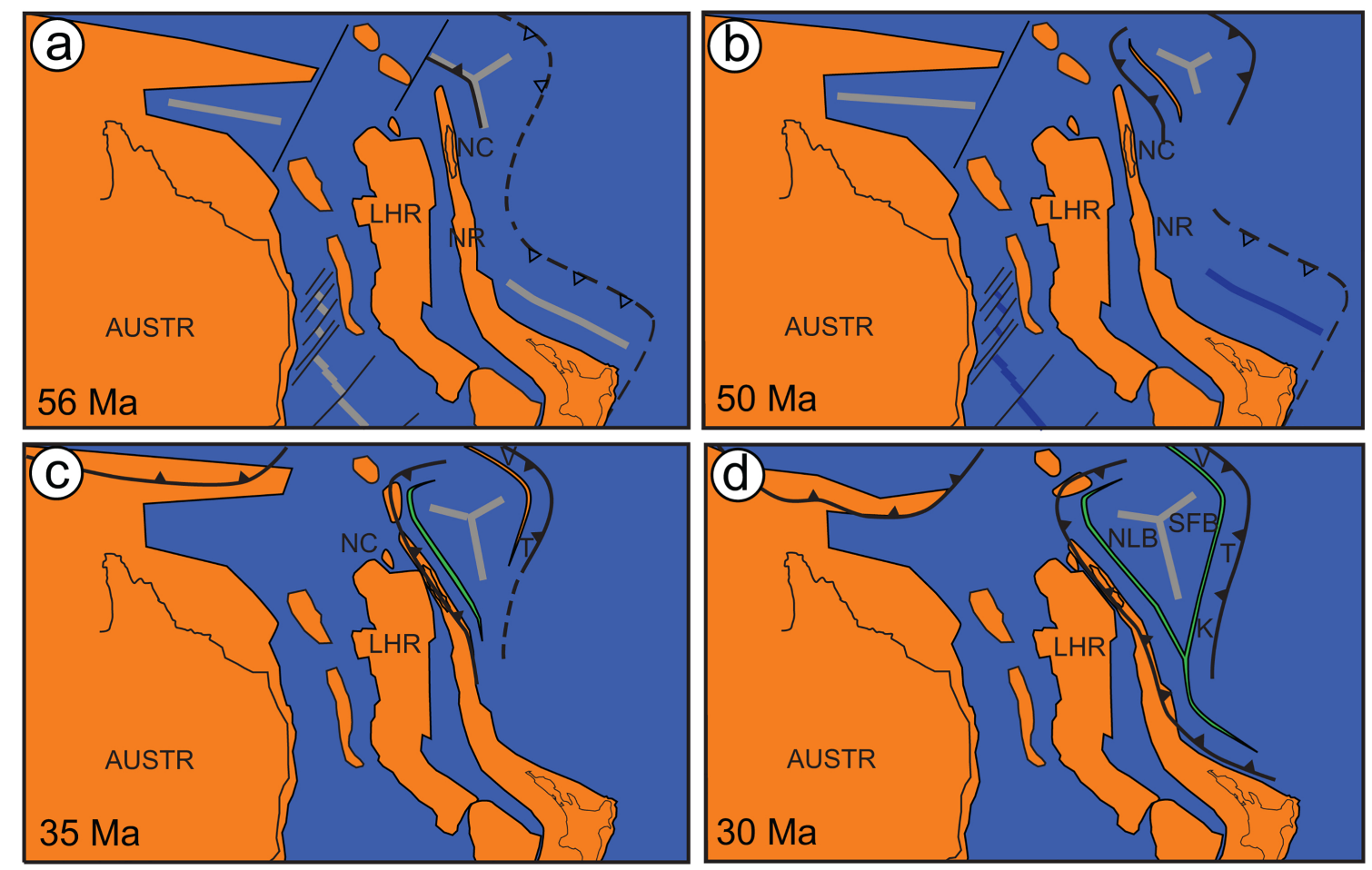

Figure 16 